\title{
A Best-Evidence Synthesis of the Relationship of Multiple Intelligence Instructional Approaches and Student Achievement Indicators In Secondary School Classrooms
}

Ethan E. Hodge

Cedarville University

Follow this and additional works at: http://digitalcommons.cedarville.edu/education_theses

Part of the Secondary Education and Teaching Commons

\section{Recommended Citation}

Hodge, Ethan E., "A Best-Evidence Synthesis of the Relationship of Multiple Intelligence Instructional Approaches and Student Achievement Indicators In Secondary School Classrooms" (2005). Master of Education Research Theses. 10.

http://digitalcommons.cedarville.edu/education_theses/10 


\title{
A BEST-EVIDENCE SYNTHESIS OF THE RELATIONSHIP OF MULTIPLE INTELLIGENCE INSTRUCTIONAL APPROACHES AND STUDENT ACHIEVEMENT INDICATORS IN SECONDARY SCHOOL CLASSROOMS
}

\begin{abstract}
A thesis submitted in partial fulfillment of the requirements for the degree of Master of Education
\end{abstract}

By

\section{ETHAN ELLIOTT HODGE}

B.A., History/Political Science, Cedarville University, 2002

B.A., Integrated Social Studies Education, Cedarville University, 2002

2005

Cedarville University 
Copyright 2005 Ethan Elliott Hodge 


\author{
CEDARVILLE UNIVERSITY \\ SCHOOL OF GRADUATE STUDIES
}

August 1, 2005

\title{
I HEREBY RECOMMEND THAT THE THESIS PREPARED UNDER MY
}

SUPER VISION BY Ethan Elliott Hodge ENTITLED A Best-Evidence Synthesis of the

Relationship of Multiple Intelligence Instruc tional Approaches and Student Achievement

Indicators In Secondary School Classrooms BE ACCEPTED IN PARTIAL

FULFILLMENT OF THE REQUIREMENTS FOR THE DEGREE OF Master of

Education

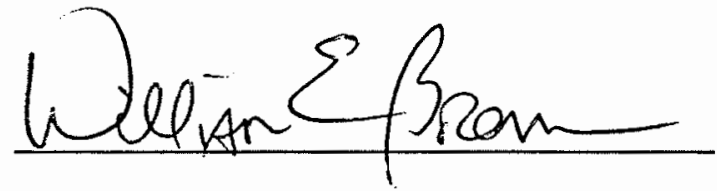

William E. Brown, Ph.D.

President

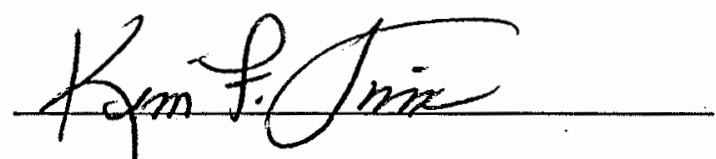

Kevin H. Sims, Ph.D.

Dean, School of Social Sciences and Professional Studies

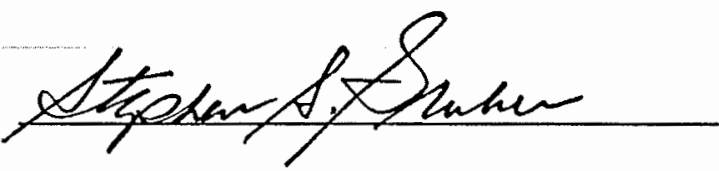

Stephen S. Gruber, Ed.D.

Education Department Chair and

Thesis Advisor

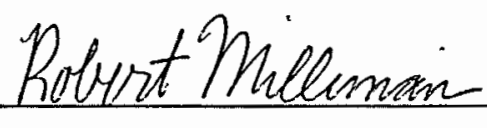

Robert W. Milliman, Ph.D.

Academic Vice President

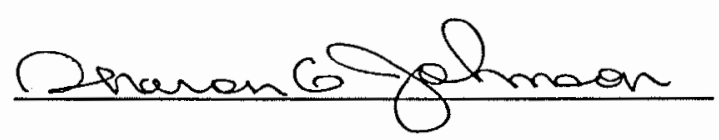

Sharon G. Johnson, D.B.A.

Director of Graduate Programs 


\begin{abstract}
Hodge, Ethan Elliott. M.Ed., Education Department, Cedarville University, 2005. $\underline{\text { A }}$ Best-Evidence Synthesis of The Relationship of Multiple Intelligence Instructional Approaches and Student Achievement Indicators In Secondary School Classrooms.
\end{abstract}

The purpose of this study was to synthesize the literature in order to assess and quantify (if possible) the relationship between MI instructional approaches and student achievement indicators in secondary school classrooms (grades 6-12). This study employed the best-evidence synthesis methodology devised by Robert Slavin. Criteria for study inclusion included germaneness, minimization of bias, and validity. This study allows for several conclusions: (1) a very limited amount of research focusing on the relationship of MI instructional approaches and student achievement indicators in secondary school classrooms exists, (2) instances of MI instructional approaches vary widely in methodology and implementation but demonstrate a fairly consistent philosophical approach, and (3) the studies included in this research synthesis failed to prove causation in the relationship of MI instructional approaches and student achievement indicators in secondary school classrooms. However, substantial evidence exists showing that multiple intelligences theory contributes positively to student learning and development. Further research is needed to quantify the relationship between MI instructional approaches and academic achievement indicators in secondary classrooms. 


\section{TABLE OF CONTENTS}

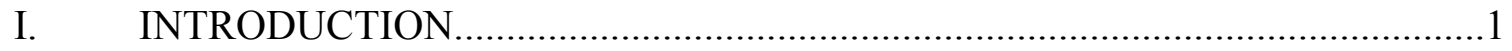

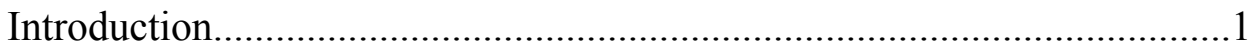

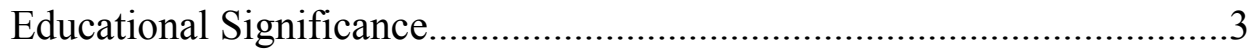

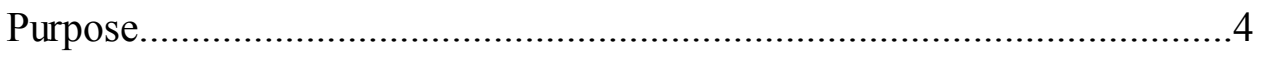

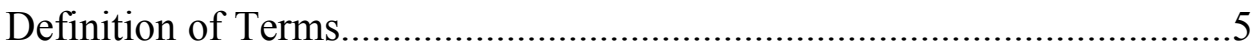

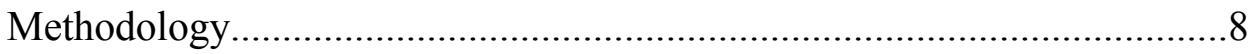

Biblical Integration................................................................

Application................................................................................

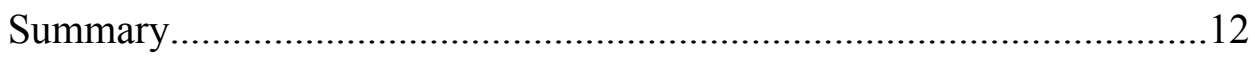

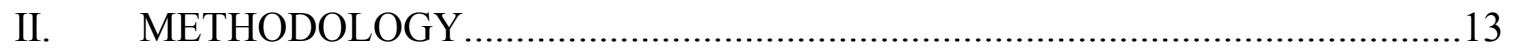

Rationale for the Best-Evidence Synthesis Methodology.......................13

The Principle of Best Evidence........................................................ 14

Study Format and Structure............................................................. 15

Criteria for Study Inclusion......................................................... 16

Literature Survey Methods............................................................ 18

Excluded Studies....................................................................... 18

Effect Size Computation............................................................20

III. LITERATURE REVIEW (BEST-EVIDENCE SYNTHESIS).........................21

A Deeper Look at MI Theory and Implementation..............................21 
Toward an MI-Based Definition of Intelligence.

Transferring Gardner's Theory to the Classroom..................................23

Project SUMIT and Three Teacher Tools............................................26

Transforming MI Theory into Educational Practice................................30

Multiple Intelligences and Assessment...............................................31

Cases 1-4 - Kornhaber, Fierros, \& Veenema (2004) [Project SUMIT]

and Campbell \& Campbell (1999)........................................................40

Project SUMIT Citations ...............................................................44

Project SUMIT Aggregate Demographic Data......................................43

Case 1 - Skyview Junior High School - Bothell, Washington.................44

Population ......................................................................44

MI Instruction and Assessment...............................................44

Research Findings..............................................................4

Case 2 - Key Renaissance Middle School - Indianapolis, Indiana...........47

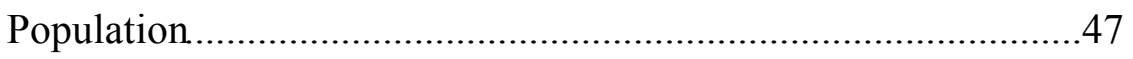

MI Instruction and Assessment..............................................47

Research Findings.............................................................50

Case 3 - Mountlake Terrace High School - Mountlake Terrace, W A......52

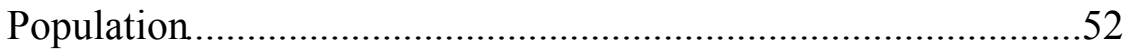

MI Instruction and Assessment..............................................52

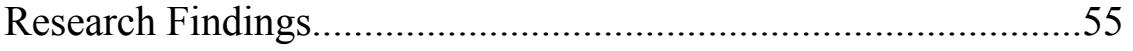

Case 4 - Lincoln High School- Stockton, California.............................56

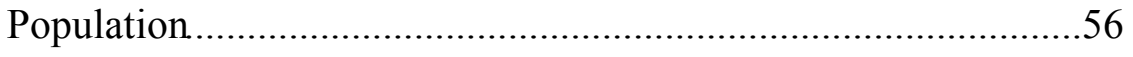

MI Instruction and Assessment................................................56 
Research Findings

Limitations of Project SUMIT and Campbell \&

Campbell Studies..............................................................58

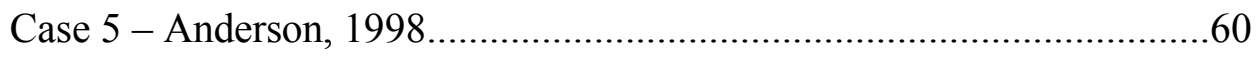

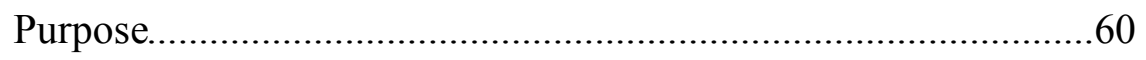

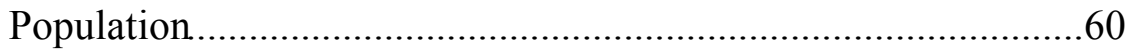

Research Design..............................................................61

Research Findings.............................................................62

Limitations of Study.........................................................63

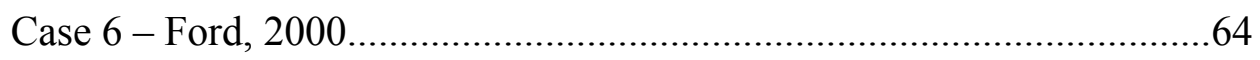

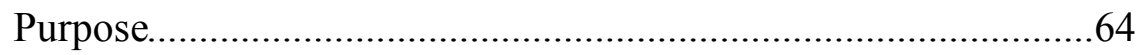

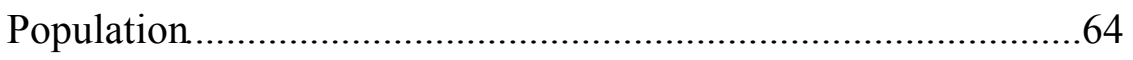

Research Design...........................................................6 65

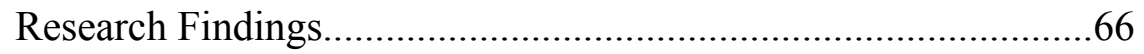

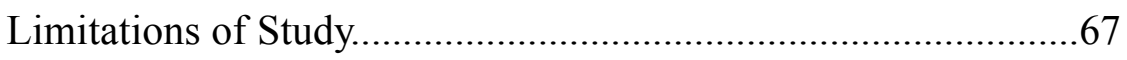

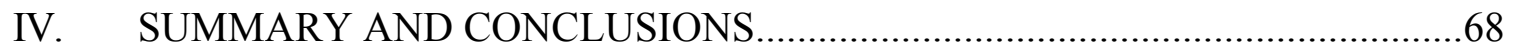

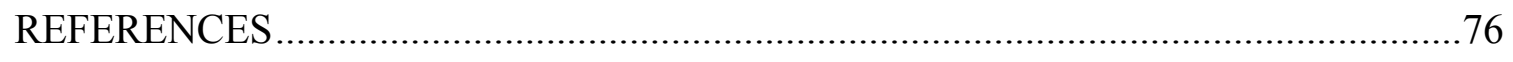

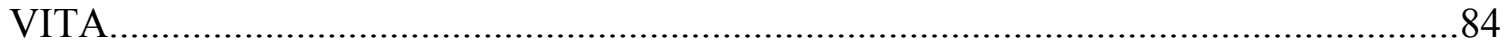




\section{LIST OF FIGURES}

Figure $\quad$ Page

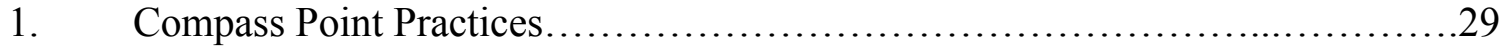

2. Schools Participating in SUMIT: Socioeconomic Status of the School

Population.............................................................. 43

3. Schools Participating in SUMIT: Race/Ethnicity of the School

Population...........................................................43

4. Mountlake Terrace High School Graduation Competencies.................................54

5. Standardized Test Outcomes Reported by Educators in Schools

Participating in SUMIT .................................................69 


\section{LIST OF TABLES}

Table

1. Excluded Studies Sorted by Primary Unmet Inclusion Criterion.........................19

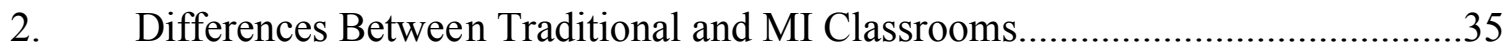

3. Studies of Multiple Intelligence Instructional Approaches in Secondary School

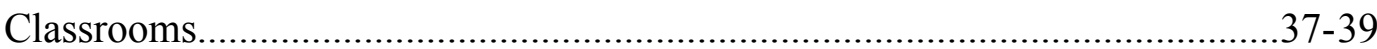

4. Achievement of Skyview Junior High School Students and Their Peers on the

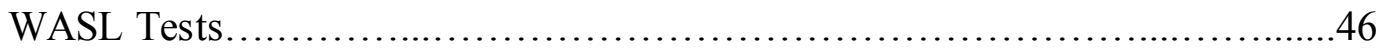

5. Key Learning Community's Scores on 1998 Indiana Statewide Testing

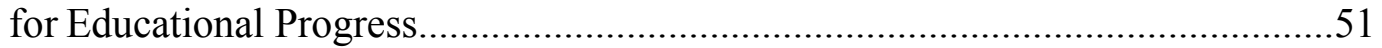

6. Comparison of Current and Past Student Vocabulary Quiz Scores..................... 62 


\section{ACKNOWLEDGEMENTS}

Many people have encouraged and supported me as I worked to complete this first phase of my graduate education. I owe all of them a large debt of gratitude.

I would like to thank the professors in the Cedarville University Education Department who have supported and encouraged me in my goal of becoming a better teacher and a more effective educational leader.

Dr. Steve Gruber, thank you for all the guidance you have provided, first as my undergraduate student teaching supervisor, subsequently as my masters thesis advisor, and now as my friend. Your counsel has been invaluable.

Dr. Phil Bassett and Dr. Cheryl Irish, thank you for arming me with instructional strategies and techniques that will allow me to reach all of my students. I have seen and learned from you how to model the love of Christ to my students.

Dr. Ed Baumann, thank you for making me think about issues I had not previously confronted from perspectives I had never considered.

Dr. Kevin Sims and Dr. Thomas Mach, thank you for giving me a love of political science and history and encouraging excellent teaching through the example of your own classroom practice.

To the faculty, staff, and especially the students of Springboro Junior High School, thank you for making my days memorable, enjoyable, and a true learning experience.

Thank you to all of the wonderful people at Cedarville University, where I also earned my undergraduate degree, for living out the faith in a vibrant way that opened my eyes to what a personal relationship with Jesus Christ should be. Special thanks to all of my undergraduate professors who consistently challenged me to evaluate all aspects of life and learning in light of God's Word.

My best friend and his wife, Mark and Melanie Boertje, thank you for your steadfast friendship, your willingness to listen, and your advice as fellow educators.

My parents, Jerry and Andrea Hodge, thank you for a lifetime of love, two godly Christian examples, and an abundant sacrificial willingness to always help me further my education. 
Finally, thank you to Jesus Christ, my Lord and my God. Without His free gift of salvation I would have neither hope of an eternity in Heaven nor a genuine relations hip with Him. His strength and wisdom have guided me through this significant undertaking.

Soli Deo Gloria! 


\section{Chapter I: Introduction}

\section{Introduction}

The theory of multiple intelligences was developed by Howard Gardner and articulated in his eminent work, Frames of Mind (1983). Gardner (1993b) was dissatisfied with the unitary concept of intelligence and the various attempts psychometricians made to measure it. Gardner advocates a move away from evaluative tests and correlation of tests to look at more natural sources of information relating to how people develop skills that are important to their culture and way of life.

Janet Davidson of Carnegie Mellon University Department of Psychology believes that there are at least three major benefits to moving away from the unitary concept of intelligence and moving toward a more inclusive definition of intelligence. First, the broader definition of intelligence is based on a convergence of evidence from divergent fields, thus increasing validity of the definition. Second, the broader definition is not bound to any specific group or context; the re-envisioned definition holds the promise of being valid in any number of situations and with many different people. Finally, she believes that this broader definition of intelligence conforms to the need for a more "dynamic assessment of intelligence" (1990). 
Thomas Armstrong (1999), in his book Seven Kinds of Smart: Identifying and Developing Your Multiple Intelligences, lends support to Gardner's theory because the theory encompasses research from a wide range of fields, including anthropology, cognitive psychology, developmental psychology, psychometrics, biographical studies, animal physiology, and neuroanatomy. Gardner (1999) incorporated the knowledge from these divergent fields and redefined intelligence as "the ability to solve problems or to create products that are valued within one or more cultural settings."

Based on his research of Gardner's work, Chen (2004) contends that for an ability to be defined as an intelligence, it must be able to be tested in terms of definitive criteria. Kornhaber, Fierros, and Veenema (2004) enunciate and concur with Chen's eight criteria which follow:

An intelligence should be isolable in cases of brain damage and there should be evidence for its plausibility and autonomy in evolutionary history. These two criteria were derived from biology.

Two criteria came from developmental psychology: An intelligence has to have a distinct developmental history with a definable set of expert end-state performances and it must exist within special populations such as idiot savants and prodigies. 
Two criteria emerged from traditional psychology: An intelligence needs to demonstrate relatively independent operation through the results of specific skill training and also through low correlation to other intelligences in psychometric studies.

Two criteria were derived from logical analysis: An intelligence must have its own identifiable core operation or set of operations and must be susceptible to encoding in a symbol system such as language, numbers, graphics, or musical notations.

\section{Educational Significance}

Armstrong (2000) asserts that multiple intelligence theory makes its greatest contribution to education by suggesting that teachers need to expand their repertoire of techniques, tools, and strategies beyond the typical linguistic and logical ones predominantly used in American classrooms.

Multiple intelligence theory resonates among teachers for a variety of reasons. One major reason is that teachers and schools are being held to higher standards than ever before due to federal and state accountability requirements (No Child Left Behind Act, 2002). Schools and districts that fail to meet accountability guidelines in a timely manner must modify their instructional approaches in order to raise student performance on standardized assessments. Applied multiple intelligence theory has potential as a 
powerful alternative to traditional instruction for this purpose. Campbell, Campbell, \& Dickinson (1999) state that many educators, acutely aware of the deficiencies and limitations of standardized measures, believe that new approaches to assessment will capture more of what students know and can do both "within and outside of school."

Multiple intelligence theory has generated a great deal of enthusiasm among some educational communities for its individualized approach and practical application in the classroom. Campbell \& Campbell (1999) assert that Gardner's theory of multiple intelligences also serves to correct negative, implicit beliefs of the teacher that diminish expectations and weaken student achievement. In his book, Becoming A Multiple Intelligences School, Thomas R. Hoerr contends that employing multiple int elligences in the classroom not only gives a diverse group of students greater opportunities to learn, but it also provides teachers and administrators with a greater means of personal and professional growth (2000).

There appears to be limited focused research syntheses which address the relationship of multiple intelligence instructional approaches and student achievement indicators within the setting of secondary school classrooms.

\section{Purpose}

The purpose of this study is to review, analyze, evaluate, and synthesize the literature in order to assess the relationship, if any, between multiple intelligences 
instructional approaches and student achievement indicators in secondary school classrooms. In the course of this study, the researcher will seek to answer the following research questions:

- What is multiple intelligences theory?

- What are the distinguishing characteristics of multiple intelligence instructional approaches?

- What is the relationship of multiple intelligence instructional approaches and student achievement indicators in secondary school classrooms?

\section{Definition of Terms}

For the purposes of this research synthesis, it is essential to define the intelligences that Howard Gardner envisioned and which will be analyzed in this study. In her September 1997 article "The First Seven....and the Eighth," in Educational Leadership, Kathy Checkley interviewed Howard Gardner. Within the context of this article, Checkley asked Gardner to define each of the intelligences. The following quotations provide Gardner's definitions of each of the eight intelligences in his own words.

Howard Gardner describes linguistic intelligence as follows.

The capacity to use language, your native language, and perhaps other languages, to express what's on your mind and to understand other people. 
Poets really specialize in linguistic intelligence, but any kind of writer, orator, speaker, lawyer, or a person for whom language is an important stock in trade highlights linguistic intelligence.

The second intelligence that Gardner explains is logical-mathematical intelligence.

People with a highly developed logical mathematical intelligence understand the underlying principles of some kind of a causal system, the way a scientist or a logician does; or can manipulate numbers, quantities, and operations, the way a mathematician does.

Spatial intelligence is the third intelligence upon which Gardner focuses. Spatial intelligence refers to the ability to represent the spatial world internally in your mind--the way a sailor or airplane pilot navigates the large spatial world, or the way a chess player or sculptor represents a more circumscribed spatial world. Spatial intelligence can be used in the arts or in the sciences.

The fourth intelligence that Gardner elucidates is bodily kinesthetic intelligence. Bodily kinesthetic intelligence is the capacity to use your whole body or parts of your body--your hand, your fingers, your arms--to solve a problem, make something, or put on some kind of a production. The most 
evident examples are people in athletics or the performing arts, particularly dance or acting.

The fifth intelligence Gardner examines is musical intelligence.

Musical intelligence is the capacity to think in music, to be able to hear patterns, recognize them, remember them, and perhaps manipulate them. People who have a strong musical intelligence don't just remember music easily--they can't get it out of their minds, it's so omnipresent.

Interpersonal intelligence is the sixth intelligence into which Gardner delves. Interpersonal intelligence is understanding other people. It's an ability we all need, but is at a premium if you are a teacher, clinician, salesperson, or politician. Anybody who deals with other people has to be skilled in the interpersonal sphere.

The seventh intelligence that Gardner defines is intrapersonal intelligence. Intrapersonal intelligences refers to having an understanding of yourself, of knowing who you are, what you can do, what you want to do, how you react to things, which things to avoid, and which things to gravitate toward.

The eighth intelligence Checkley discussed with Gardner is the naturalist intelligence. 
Naturalist intelligence designates the human ability to discriminate among living things (plants, animals) as well as sensitivity to other features of the natural world (clouds, rock configurations).

\section{Methodology}

A general overview of multiple intelligence theory and multiple intelligence instructional approaches will precede reviews of studies that examine how this theory has been operationalized and implemented in secondary school classrooms. Results of these studies will be evaluated and synthesized in order to draw conclusions regarding the influence, if any, of multiple intelligence theory and application in secondary school classrooms.

This research survey will employ the best-evidence synthesis methodology devised by educational researcher Robert Slavin. In his November 1986 Educational Researcher article, "Best-Evidence Synthesis: An Alternative to Meta-Analytic and Traditional Reviews," Slavin clearly delineates the principles of this methodology. The purposes and goals of this methodology, as articulated by Slavin (1986), are as follows:

Best-evidence synthesis incorporates the quantification and systematic literature search methods of meta-analysis with the detailed analysis of critical issues and study characteristics of the best traditional reviews in an attempt to provide a thorough and unbiased means of synthesizing research and providing clear and useful conclusions. (p. 10) 
At the heart of this methodology is the "best-evidence" principle which demands that reviewers consistently apply well-defined and well-justified criteria prior to selecting literature for inclusion in the research synthesis. Following the creation and application of consistently applied and well-reasoned criteria, a comprehensive search of the literature must take place. The ultimate goal of a best-evidence synthesis is to "produce and defend conclusions based on the best available evidence, or in some cases [may] conclude that the evidence currently available does not allow for any conclusions" (Slavin, 1986).

This study will attempt to locate approximately twenty research studies that will be analyzed and evaluated, and then synthesized to answer the research questions and draw conclusions (if possible) regarding the relationship of multiple intelligence instructional approaches and student achievement indicators, if any, in secondary school classrooms.

\section{Biblical Integration}

From a biblical worldview, there are aspects of multiple intelligence theory that conform to Scripture as well as aspects which do not conform to Scripture. The concept of individuals as uniquely gifted beings predisposed to certain aptitudes and abilities appears in both the Old and New Testaments of the Bible. The construction of the tabernacle following the Hebrew exodus is instructive. The biblical narrative in Exodus 35:29-36:4 (New American Standard Bible) depicts some of the tabernacle's construction 
and the provision of its furnishings. This passage demonstrates that a multiplicity of artisans and craftspeople were involved in producing specific objects which they were uniquely suited to create. In I Corinthians 12:4-7, in a discourse pertaining to spiritual gifts, the apostle Paul points out that each individual is gifted in a unique way for ministry in the church body. He also makes the point that the God-given predisposition for differentiated aptitudes contributes to the success of the church. I Corinthians 12:1821 acknowledges the need for a diversified church body and points out the difficulties that would arise if all believers possessed the same dispositions.

There is at least one major aspect of multiple intelligence theory that flies in opposition to a biblical worldview. According to Gardner (1993a), for an ability to be defined as an intelligence, there should be evidence for its plausibility and autonomy in evolutionary history. A biblical worldview acknowledges a personal, active Creator and holds to a literal seven day Creation week. This is only one of the various aspects of multiple intelligence theory that holds within it an implicit acknowledgement of natural selection and other Darwinian principles.

\section{Application}

Application of multiple intelligence theory into classroom pedagogical practice has a wide-ranging impact on students, teachers, and learning in the classroom. In the journal Education, Jennifer Nolen focuses specifically on the academic application of multiple intelligence theory. She describes several of the learning benefits of teachers 
employing multiple intelligence theory in the classroom. She contends that when instruction is individualized based upon the intelligences of each of the students, learning is optimized for the entire class. Multiple intelligence theory restructures the classroom to focus on individual learners and refocuses the teacher's attention to meeting individual student needs. Nolen (2003) also says that instruction based on multiple intelligence theory helps teachers recognize successful students who are active learners.

Gibson and Govendo (1999) begin their article by noting that a great deal has been written concerning the use of multiple intelligence theory for academic tasks. They proceed to describe applications of multiple intelligence theory in relation to the affective aspects of classrooms. These aspects they address include the physical and social environment, classroom customs and routines, transitions, and social skills and problemsolving. In conclusion, they promote both the academic and social application of multiple intelligence theory as a means to help young adolescents reach their potential.

The academic goals enunciated by Nolen and the affective goals delineated by Gibson and Govendo (1999) have a direct application to the researcher's current educational setting. The district continuous improvement plan, district strategic plan, and building goals of the researcher's current educational setting call for student-centered, differentiated, and individualized instruction. In addition to meeting district and building goals, the researcher's professional goals include furthering the development of his classroom as a place for learning and encouraging the cognitive and affective development of his students. 


\section{Summary}

As American public schools enter an era focused on increasing student learning, school accountability, and test scores, new instructional approaches will be implemented and evaluated. This research synthesis will survey and assess the literature regarding the implementation of one of the most discussed and relatively new theories in education, the theory of multiple intelligences. This study will evaluate the literature regarding the application of multiple intelligence theory into classroom pedagogical practice in order to determine what, if any, relationship exists between implementation of multiple intelligence theory and indicators of student achievement. This research synthesis will focus exclusively on the implementation of the theory and any related effects in junior high, middle school, and high school classrooms (grades 6-12). 


\section{Chapter II: Methodology}

Slavin $(1986,1995)$ clearly and thoroughly describes the format, content, and structural elements of a best-evidence synthesis. In formulating this study, the research found a number of best-evidence syntheses to see examples of Slavin employing his methodology; these examples include Gutierrez \& Slavin (1992), Slavin (1987), Slavin (1990), and Slavin \& Cheung (2003).

\section{Rationale for the Best-Evidence Synthesis Methodology}

Slavin (1995) begins explaining his best-evidence synthesis approach and provides a rationale for this new approach that begins by describing the limits of traditional narrative reviews. According to Slavin, there are three major limitations to narrative reviews: traditional reviews generally do not include studies based on a set of well-defined criteria, the problem of "reviewer bias" in choosing or excluding studies for the review, and the general lack of a "systematic method" for synthesizing the data and making conclusions based on the evidence (pp. 9-10). Slavin goes on to argue that traditional meta-analytical approaches tend to be "mechanistic" and can lead researchers to draw misleading conclusions. Slavin argues for his methodological approach in claiming, "best-evidence synthesis adds to the traditional scholarly review application of 
rational, systematic methods of selecting studies to be included and use of effect size as a common metric for treatment effects" (p. 11).

\section{The Principle of Best Evidence}

The cornerstone of Slavin's approach is the principle of best evidence. Slavin (1995) clearly articulates and explains the transference of this legal concept into the realm of educational research.

In law, there is a principle that the same evidence that would be essential in one case might be disregarded in another because in the second case there is better evidence available... Best-evidence synthesis extends this principle to the practice of research review. For example, if a literature contains several studies high in internal and external validity, then lower quality studies might be largely excluded from the review... If a set of studies high in internal and external validity does not exist, we might cautiously examine the less well designed studies to see if there is adequate unbiased information to come to any conclusions... The principle of best evidence works in law because there are $a$ priori criteria for adequacy of evidence in certain types of cases. (pp. 11-12)

Slavin contends that devising a priori criteria will lead to a selection of studies that will provide better evidence than those studies typically selected for traditional narrative reviews. Setting up these criteria in advance eliminates researcher bias in selecting or 
excluding studies. These a priori criteria give a greater focus to the study and lead to a greater concentration on the specific details of the subject(s)/concept(s) being considered.

\section{Study Format and Structure}

Through direct observation of Slavin's own work in the realm of best-evidence syntheses, it is possible for the researcher to derive a general format and structure for this type of study. An instructive example is Slavin's 1990 work on ability grouping in secondary schools; it provides a good example that will assist researchers who wish to employ his methodology. Employing Slavin (1990) as an example allows the researcher to derive the following structure and format for a best-evidence synthesis.

The study opens with an introduction to the topic at hand that provides the history and general information related to the concept(s) being studied. The next component is a section that describes the methods employed in the review, with subsections focusing on criteria for study inclusion, literature search procedures, and a final subsection that deals with the computation of effect sizes. Following the methodology section, the research synthesis is presented. In this section, a table lists and provides a glimpse of each of the studies selected for inclusion in the synthesis. A discussion of the findings and implications follows this table. The final component of the best-evidence synthesis describes the limitations of the review, provides the researcher's conclusions, along with the standard references section and any necessary appendices. 


\section{Criteria for Study Inclusion}

Slavin (1995) provides three general guidelines for establishing criteria for the inclusion of studies in a best-evidence synthesis. He acknowledges that the specific criteria depend on the intended purpose of the review; however, he provides general guidelines that have been used by this researcher for the purposes of this study. He states,

First, the most important principle of inclusion must be germaneness to the issue at hand... Second, methodological adequacy of studies must be evaluated primarily on the basis of the extent to which the study design minimized bias... Third, it is important to note that external validity should be valued at least as highly as internal validity in selecting studies for a best-evidence synthesis... One category of studies that may be excluded in some literatures is studies with very small sample sizes. Small samples are generally susceptible to unstable effects. (p.13) These guidelines provide the framework for this study. Each aspect is of equal importance, and the application of each guideline to the criteria established for this study is listed below.

The issue of germaneness is critical to the successful application of the bestevidence synthesis approach. For inclusion in this synthesis, a study must focus exclusively on the relationship between multiple intelligence instructional approaches and student achievement indicators. For the purposes of this study, student achievement 
indicators refer to student grades on classroom assignments or scores on a standardized assessment. The researcher acknowledges that this definition of academic achievement flies in the face of Gardner's stated desire to move away from evaluative tests (1993b). In addition, the researcher acknowledges that classroom grading practices vary widely and may impact the validity of comparing grades from one teacher's classroom to grades in another teacher's classroom. However, one of the major goals of this study is to determine if there is any relationship and/or causal link between Gardner's theory and improvement on standardized, evaluative, and/or teacher-made tests (through the inclusion of class grades as an indicator of academic achievement). With this goal in mind, the need for this definition of academic achievement indicator becomes apparent.

In addition to germaneness, studies included in this synthesis must meet certain demographic criteria in the populations they study. This synthesis will include studies of general education students in grades 6-12, attending schools in the United States. Several studies targeted at exceptional student populations (special education students, gifted students, ESL students, etc.) have been excluded from this synthesis. Slavin's second general guideline of selecting studies whose designs minimize bias is also essential. This synthesis has included studies that minimize bias through careful design, control and selection procedures.

Validity is a key element in the evaluation of any research study or research synthesis. Slavin (1995) argues against the inclusion of "extremely brief laboratory studies or other highly artificial experiments" (p.13). This guideline was incorporated 
into the methodological approach of this best-evidence synthesis. This synthesis only included studies that have a duration of at least one year and a sample size where $\mathrm{N}=75$ participants.

\section{Literature Survey Methods}

Studies included in this best-evidence synthesis were located through an extensive search procedure. Primary sources for the studies included are Education Abstracts, Educational Resources Information Center (ERIC), EBSCOhost Professional Development Collection, and ProQuest Dissertations and Theses. Primary sources, trade publications, and citations from other reviews and articles also provided a means to locating studies that fit the a priori criteria detailed above. Every attempt was made to obtain a complete set of studies that met the aforementioned criteria.

\section{Excluded Studies}

The researcher found a number of qualitative, narrative, and/or descriptive studies that presented very little or no quantitative data. These studies were excluded because they do not help to show and/or to quantify the relationship between multiple intelligence instructional approaches and indicators of student achievement. Furthermore, and of greater importance, they do not meet the aforementioned criteria for study inclusion. Each study, denoted by author and primary unmet inclusion criterion appears in Table 1. 
TABLE 1

Excluded Studies Sorted By Primary Unmet Inclusion Criterion

\begin{tabular}{|c|c|c|}
\hline $\begin{array}{c}\text { Germaneness } \\
\text { (including demographic criteria) }\end{array}$ & $\begin{array}{l}\text { Minimization of Bias } \\
\text { (design and procedures) }\end{array}$ & $\begin{array}{c}\text { Validity } \\
\text { (including sample size) }\end{array}$ \\
\hline $\begin{array}{l}\text { Beam, } 2000 \text { - demographic; } \\
\text { Bouton, } 1997 \text { - germaneness; } \\
\text { Dobbs, } 2001 \text { - demographic; } \\
\text { Feeney, } 1999 \text { - germaneness; } \\
\text { Fisher, } 1997 \text { - demographic; } \\
\text { Franzen, } 1999 \text { - germaneness; } \\
\text { Hicks, } 1998 \text { - demographic; } \\
\text { Maddox, } 2002 \text { - germaneness; } \\
\text { McGraw, } 1997 \text { - germaneness; } \\
\text { Muehlbauer, } 2000 \text { - demographic; } \\
\text { Nguyen, } 2000 \text { - demographic; } \\
\text { Shalk, } 2002 \text { - germaneness; } \\
\text { Sohn, 2003 - germaneness; } \\
\text { Snyder, } 2000 \text { - germaneness; } \\
\text { VanGilder, } 1995 \text { - demographic; } \\
\text { Walker, } 2001 \text { - germaneness }\end{array}$ & $\begin{array}{l}\text { Martin, } 1999 \text { - unvalidated } \\
\text { assessment instrument }\end{array}$ & Gooch, 2002 - sample size \\
\hline
\end{tabular}




\section{Effect Size Computation}

Slavin (1995) acknowledges the work of Gene Glass as the first to use effect size as a part of meta-analysis and as a means of measuring treatment effects. Kavale (2001) details the mathematical procedures for deriving the effect size statistic.

The basic statistic in meta-analysis is the effect size (ES), defined by

$$
\mathrm{ES}=\frac{\overline{\mathrm{X}} \mathrm{E}-\overline{\mathrm{X}} \mathrm{C}}{\mathrm{SDC}}
$$

Where $\mathrm{XE}=$ average score of the experimental group, $\mathrm{XC}=$ average score of the control group, and SDC = standard deviation of the control group. (p. 181)

For the purposes of this review, all effect size statistics have been computed using the procedures Kavale (2001) detailed above. Cohen (1988), quoted in Kovale (2001), provided a general interpretive guide to the statistical power of treatments based on computed effect size statistics. "These ES classifications include the descriptions of small (.20), medium (.50), or large (.80).” These coefficients are $z$ scores that demonstrate the standard deviation advantage offered by the application of any given treatment to the experimental group in comparison to the control group in any given experiment. 


\section{Chapter III: Literature Review (Best-Evidence Synthesis)}

\section{A Deeper Look at MI Theory and Implementation}

The heart of the multiple intelligences theory rests with individualization and recognition of divergent abilities. In numerous works, Gardner argues against standardization and goes as far as decrying attempts to devise a best methodology for implementing the theory. However, this approach leaves the theory quite nebulous in real-world situations and leaves implementation entirely open to the interpretation of practitioners. Any scientific, empirically-based research study must be an outgrowth of standardized methodology and procedures. In reviewing the literature, this researcher found the Project SUMIT study, with the Entry Points Framework and the Compass Point Practices, superior in methodological approach and research basis. Kornhaber, Fierros, \& Veenema (2004) provide their pedigree and their purpose.

The Compass Point Practices stem from the work of a three-and-a-half year research investigation based at Project Zero, called the Project on Schools Using MI Theory or SUMIT. SUMIT was founded by the Schwab Foundation for Learning and the Geraldine R. Dodge Foundation. Its aim was to identify, document, and disseminate practices that are employed in schools that link MI with benefits for students. (p. 11) 
A number of other researchers have dealt with multiple intelligences theory in the classroom (Armstrong, 1999, 2000, 2003; Campbell, Campbell, \& Dickinson, 1999; Hoerr, 2000; Lazear, 1994, 1999; Silver, Strong, \& Perini, 2000); however, their approaches were generally inferior in approach and psychometric qualities to the Project SUMIT study. While valuable for practitioners, the work of these researchers is outside the scope of this study since it is generally not quantitative in nature.

\section{Toward an MI-Based Definition of Intelligence}

A hallmark of multiple intelligences (MI) theory is Howard Gardner's attempt to redefine intelligence, moving away from the generally accepted conceptualization of general intelligence, an unwavering unitary concept, known as $g$. Kornhaber, et al. (2004) clarify this attempt and describe Gardner's theoretical conception of intelligence as multiple, rather than a singular construct.

Rather than defining intelligence in terms of mental test results, or IQ scores, Gardner defined an intelligence as a psychobiologic al potential to solve problems or fashion products that are valued in one or more cultures

(Gardner, 1999). In other words, an intelligence is the capacity inherent in the human brain that is developed and expressed in social and cultural contexts. (p. 4)

Gardner hoped to draw other psychologists into a dialogue regarding the nature of intelligence, but instead drew in a congregation of enthusiastic educators who believed (somewhat implicitly) that his theory was at least partially correct because it conformed 
to their classroom experiences. Gardner (2004) explicitly states his surprise at the attention his theory, in the form of his 1983 work, Frames of Mind, drew from professional educators.

I anticipated that my chief audience would be other psychologists, as well as that segment of the general public that follows discussion of key psychological concepts. In fact, however, even though the book contained only a few pages about educational implications, the chief audience by far turned out to be educators - in the United States, initially, and eventually in many other regions of the world.

\section{Transferring Gardner's Theory to the Classroom}

It is important to note that Gardner is not an educator by training, he is a psychologist. Therefore, educators may experience difficulty in transferring a somewhat abstract psychological theory into a classroom filled with dynamic children. In applying Gardner's theory to the classroom, Kornhaber et al. (2004) point out several caveats that are notable and could influence teacher perception, and ultimately implementation of multiple intelligences theory.

There are several important points about MI that are especially important for educators to keep in mind: First, Gardner notes that the exact number of intelligences is less important than the notion that intelligence is multiple rather than primarily dependent on $g$. Over time, Gardner may find other abilities that quantify as intelligences when judged against his 
criteria. In fact, the naturalist intelligence was established several years after the others, once evidence to support it had been uncovered.

Second, barring brain damage, all individuals possess all the intelligences. Though we have often heard educators or parents describe a youngster as "bodily-kinesthetic" or "linguistic," this convenient shorthand runs counter to the theory. What differs across people is not the intelligences they possess, but their profiles of intelligence [emphasis in original]. That is, individuals differ with regard to the relative strengths and weakness among their intelligences.

...a third nuance stems from the theory's focus on real-world roles. Even a brief consideration of real-world roles - journalist, mathematician, dancer - reveals that each real-world role draws on a combination of intelligences [emphasis in original]. (pp.6-7)

Caveats two and three have the greatest influence on teacher thinking and practice. Classroom practices based on multiple intelligences theory focuses on children as dynamic and interactive beings whose abilities cannot easily be tracked and quantified on a continuum with distinct intervals.

Multiple intelligences theory views each learner as a mosaic of abilities and interests. The draw for teachers is the opportunity to use those diverse abilities and interests to create a classroom environment more conducive to learning. Several research studies have delved into the question of why teachers choose to adopt MI. Apart from her Project SUMIT colleagues, Mindy Kornhaber researched this phenomenon. Her 
article, Multiple Intelligences: From the Ivory Tower to the Dusty Classroom - But Why? (2004) synthesized five general reasons why teachers choose to adopt MI in their classrooms.

MI validated what educators already know... MI complemented educators' existing philosophies and beliefs... Educators already used some practices that fit with the theory... MI provided a framework for organizing educators' practice... Educators reported that MI helped extend their practice... (pp. 68-69)

Educating from a multiple intelligence perspective is purported to create an educational environment more attuned to individual student's cognitive and affective development. Due to its more individualized approach and in some cases improper application of the theory, multiple intelligence theory does have its detractors. Kornhaber et al. (2004) elaborate on the somewhat difficult task of implementing this cognitive development theory in the classroom, along with some of the consequences when MI is not appropriately used.

...some awkward things happen when MI - a tool for understanding cognitive abilities - is used as a tool for curriculum development. Superficial activities may become more frequent and some of the substance of the curriculum may be sacrificed. Because of such problems, MI has sometimes been criticized for watering down standards, rather than enabling richer learning across the student population. To use MI well, 
one needs tools aimed more specifically at developing curriculum that engages learners who have different profiles of intelligence... (p. 7)

This statement neatly ties together the disparate elements of theory and practice - the researchers acknowledge that certain tools are necessary to bridge the gap between theory and implementation. Howard Gardner recognized the difficulties inherent in theory implementation and began devising a framework to alleviate these difficulties and clarify the process. Gardner devised an early construct of the "Entry Points Framework" first in Gardner (1991) and then reworked them in his 1999 book, The Disciplined Mind: What All Students Should Understand.

\section{Project SUMIT and Three Teacher Tools}

The three teacher tools embedded in the Project SUMIT study are (1) Multiple Intelligence Theory, (2) Entry Points Framework, and (3) Compass Point Practices. According to Kornhaber et al. (2004), the Entry Points Framework and the Compass Point Practices are the two primary curricular/implementation tools that alleviate and clarify the process of putting multiple intelligences theory into educational practice. Entry Points allow the classroom teacher to link profiles of individual intelligence to the academic material that is being taught. Kornhaber et al. (2004) delineate each of the entry points.

Narrative: The narrative entry point deals with the story or stories that are central to a topic. Typically a rich, or "generative," topic will offer 
several possible narrative entry points, some of which may be recounted or performed as dramatic narratives...

Logical-Quantitative: This entry point focuses on numerical aspects of a topic and/or on deductive, logical reasoning, of the sort that can often be captured by if-then syllogisms...

Aesthetic: The aesthetic entry point engages artistic aspects of, or representations of, a topic. It may also focus on sensory features associated with the topic...

Experiential ("Hands-on"): This entry point provides students opportunities to do work involving the physical 'stuff' of the topic... Interpersonal: The interpersonal entry point involves working together with others to learn about a topic...

Existential/Foundational: This entry point deals with fundamental, philosophical questions about the nature of the topic, why it exists, and/or what is its meaning or purpose... (pp. 8-9)

These entry points are means for teachers to link pedagogical practices with the various profiles of individual intelligence that their students manifest. The addition of the Entry Points Framework to multiple intelligences theory and the usage of multiple entry points allows teachers to provide students with multiple perspectives on a single topic (Kornhaber et al., 2004). Another possible consequence of employing more than one of the entry points is the further development of each student's profile of individual intelligence. 
The two tools that have been discussed so far, multiple intelligence theory and the Entry Points framework, lay the groundwork for classroom implementation and the creation of a multiple intelligence learning environment. According to Kornhaber et al. (2004), a third tool-Compass Point Practices - is needed to carry multiple intelligences theory beyond the classroom and to allow for its implementation on a school-wide level. A sound set of organizational practices can help teachers to sustain and develop the good work that they do in their own classrooms. Such practices can also enable teachers throughout a school to build knowledge and skills across a wide range of learners. Therefore, in addition to a tool for understanding individual learners' strengths [MI Theory] and a tool for building curriculum [Entry Points Framework], we need a tool for organizational practice [Compass Point Practices]. (p. 11)

Compass Point Practices carry MI innovation to the entire school and help create the culture necessary to sustain change and allow for school-wide implementation of multiple intelligences theory-based educational methods. Kornhaber et al. (2004) elaborate on the rationale and meaning of the Compass Point Practices.

...Compass Point Practices....are practices found in schools that use MI and that associate the theory with benefits for students. They can guide you toward developing schools and classrooms that support students who learn in many different ways. The Compass Point Practices provide a tool for thinking systematically about classrooms and schools, for identifying areas of practice that are strong and those that can be made stronger. (p. 11) 
Figure 1. The Compass Point Practices.

\section{THE COMPASS POINT PRACTICES}

\section{Culture: a supportive environment for educating diverse learners.}

The school environment is notable for a belief in students' strengths and potential, care and respect, joy in learning, and educators' hard work.

\section{Readiness: awareness-building before implementation}

There are efforts to introduce and explore MI and other new ideas prior to calls for implementing them in classrooms.

\section{Tool: $M I$ is a means to foster} high-quality student work

MI is used as a route to promote students' skills and understanding of curriculum, rather than as an end in itself or as an additional piece of the curriculum.

\section{Collaboration: informal and formal exchanges}

In informal and formal exchanges, educators readily share ideas, provide constructive suggestions, and complement their own areas of strength by drawing on the knowledge and strengths of others.

\section{Controlled Choice: meaningful curriculum and assessment options}

Educators provide students wtih options for learning and for demonstrating their knowledge that are meaningful both to the student and in the wider society.

Arts: a significant role in the life of the school

The arts are used to develop students' skills and understanding within and across disciplines.

(Kornhaber, Fierros, \& Veenema, 2004, p. 29) 


\section{Transforming Multiple Intelligence Theory into Educational Practice}

Since Howard Gardner is the originator of multiple intelligence theory, it is appropriate to include his viewpoint on how educators have interpreted and implemented his theory. In the Foreword to Kornhaber, Fierros, \& Veenema (2004), Gardner gives a fairly explicit demonstration of his dissatisfaction with many of the ways his cognitive development theory has been interpreted, implemented, and documented in the classroom.

Much - perhaps too much - has been written about MI theory from the perspective of educational practice. Nearly all of what has been written has come from individual practitioners. Much of this writing suffers from one of two flaws: (1) the author has only a superficial understanding of the theory - indeed, sometimes I have wondered whether the author has even read the original publications; (2) the author is promoting a particular set of practices, often to the exclusion of other, equally tenable ones. (p. xii)

Indeed, this researcher found a great deal of literature that deals only with the implementation component in descriptive, qualitative manner and devotes little (if any) study to the theoretical underpinnings of the implementation or any quantitative data related to student academic achievement indicators where the theory has been implemented in educational settings. 


\section{Multiple Iintelligences and Assessment}

In transforming multiple intelligences theory into educational practice, assessment is a necessary component. Assessment in a multiple intelligence-based educational setting involves at least two aspects: (1) assessment of individual student profiles of intelligence and (2) assessment of student learning. Gardner (1993a) stated his definition of assessment in his work, Frames of Mind. "I define assessment as the obtaining of information about the skills and potentials of individuals, with the dual goals of providing useful feedback to the individuals and useful data to the surrounding community." Gardner's somewhat lofty definition of assessment does not adequately and explicitly describe what should be involved in multiple intelligences assessment. Johnson(1996) makes the claim that in "Gardner's Ideal School" there would be "an assessment specialist providing regular updated intelligence evaluations of each student's strengths, weaknesses, and inclinations." In the realm of education, seldom is "ideal" equal to reality. However, the issue of assessing individual profiles of intelligence is key to using multiple intelligences theory in the classroom. Chen (2004) provides four essential criteria for effective methods of assessment in a multiple intelligence-based educational environment.

For one, accurate assessment of multiple intelligences demands a range of measures that tap the different facets of each intellectual capacity. Also, intelligence-fair instruments are needed to assess the unique faculties of each intelligence... Further, the assessment must be an ongoing process based on multiple samples of an individual's abilities over time in 
different contexts, taking into consideration the child's educational and cultural experiences. Finally, assessments of multiple intelligences are designed to identify and build on individuals' strengths by creating rich educational environments with learning opportunities that match children's specific abilities and interests... (p.20)

Several researchers (Armstong, 2000; Silver, Strong, \& Perini, 2000) have delved into inventories and assessments related to individual profiles of intelligence; however, the only assessment strongly supported by a large body of empirical research and validity testing is the Multiple Intelligences Developmental Assessment Scales (MIDAS) devised by C. Branton Shearer. Shearer (2004b) explains the role of his work in relation to multiple intelligence theory.

MIDAS research shows that the MI profile can provide a reasonable estimate of a person's intellectual disposition and that the process of verification can provide teachers (and students) with a rich appreciation of the primary domains associated with all the intelligences. (p. 158)

Shearer explains the development process of the MIDAS and explains how it can serve as a tool to promote teacher development and student achievement (2004b).

The MIDAS was developed over a period of 6 years using a combination of rational and empirical methods of test construction using MI theory as a basis to guide interpretation of empirical results. Initially, a large number of items $(n=125)$ was generated through a careful reading of the behavioral characteristics of each intelligence as articulated in Frames of 
Mind (Gardner, 1993). Subject area experts (including Howard Gardner) reviewed these questions. Items were then field tested via in-depth interviews, whereby interviewees provided feedback on question wording and content clarity. A series of quantitative studies were then conducted to examine inter-informant and test-retest reliability, item response patterns, and interitem correlations... Based on these results, individual scales for each intelligence were constructed and a scoring system was devised. Eventually, within scale factor analyses were conducted to create and verify a number of domain-specific subscales within each of the intellectual scales. (p. 148)

Shearer's has worked with the MIDAS for more than fifteen years. This lengthy period of continuous development along with the statistical measures demonstrating the reliability and validity of the MIDAS lend considerable weight to this assessment tool. In regard to the second aspect of multiple intelligences assessment (classroom assessment), Lazear (1994) listed eight guidelines for assessment in a multiple intelligence-based educational setting.

- Assessment design and execution should include educators who work with the students.

- Assessment requires time and effort; educators should be given appropriate time to create and administer instruments.

- Assessment should be authentic and central to the educational process.

- Assessment should drive the curriculum. 
- Assessment practices should be designed for students' benefit.

- Assessment practices should mirror assessment in 'the real world.'

- Assessment should be individualized and developmentally appropriate.

- Assessment requires that students become active partners in demonstrating learning.

Permeating the literature is the recurrent theme that multiple intelligences theory (in the classroom context) is more a way of thinking than a specific set of practices and procedures for implementing the theory. Hoerr (2003) provides contrasting views of the traditional classroom and the MI classroom. 
TABLE 2

Differences Between Traditional and MI Classrooms

\begin{tabular}{|c|c|}
\hline In a traditional classroom & In an MI classroom \\
\hline $\begin{array}{l}\text { The kids with strong scholastic } \\
\text { intelligences are smart and the other kids } \\
\text { are not. }\end{array}$ & $\begin{array}{l}\text { Everyone has a different profile of } \\
\text { intelligences; we are all smart in different } \\
\text { ways. }\end{array}$ \\
\hline Teachers create a hierarchy of intellect. & $\begin{array}{l}\text { Teachers use all students' intelligences to } \\
\text { help them learn. }\end{array}$ \\
\hline The classroom is curriculum-centered. & The classroom is child centered. \\
\hline $\begin{array}{l}\text { Teachers help students acquire information } \\
\text { and facts. }\end{array}$ & $\begin{array}{l}\text { Teachers help students create meaning in a } \\
\text { constructivist way. }\end{array}$ \\
\hline $\begin{array}{l}\text { The focus is on the scholastic intelligences, } \\
\text { the } 3 \text { R's. }\end{array}$ & $\begin{array}{l}\text { The Personal Intelligences are valued: Who } \\
\text { you are is more important than what you } \\
\text { know. }\end{array}$ \\
\hline Teachers work from texts. & $\begin{array}{l}\text { Teachers create curriculum - lessons, units, } \\
\text { themes. }\end{array}$ \\
\hline $\begin{array}{l}\text { Teachers assess students by paper and } \\
\text { pencil 'objective' measures. }\end{array}$ & $\begin{array}{l}\text { Teachers create assessment tools - } \\
\text { Projects, Exhibitions, Portfolios (PEPs) - } \\
\text { which incorporate MI. }\end{array}$ \\
\hline $\begin{array}{l}\text { Teachers close the door and work in } \\
\text { isolation. }\end{array}$ & $\begin{array}{l}\text { Teachers work with colleagues in using } \\
\text { MI, developing collegiality. }\end{array}$ \\
\hline
\end{tabular}

(Hoerr, 2003, p. 94) 
Slavin's best-evidence synthesis methodology calls for a table of study characteristics in the literature review portion of the study. Such a table for this study follows. Each of the seven selected studies are described in terms of source, grade level, geographic location, sample size, study duration, study design, and treatment effect size (if sufficient data was provided to allow for the computation of effect size). 


\section{TABLE 3}

Studies of Multiple Intelligence Instructional Approaches in Secondary School Classrooms

\begin{tabular}{|c|c|c|c|c|c|c|}
\hline Article & Grades & Location & Sample & Duration & Design & Effect Sizes \\
\hline $\begin{array}{l}\text { Campbell \& } \\
\text { Campbell, } 1999 \\
\text { and Kornhaber, } \\
\text { Fierros, \& } \\
\text { Veenema, } 2004 \\
\text { [Project SUMIT] }\end{array}$ & $7,8,9$ & $\begin{array}{c}\text { Skyview Jr. High } \\
\text { Bothell, WA }\end{array}$ & 900 & Since 1992 & $\begin{array}{l}\text { Telephone interviews } \\
\text { with educators at } 41 \\
\text { schools [SUMIT]; all } \\
\text { schools have been } \\
\text { employing MI for at } \\
\text { least } 3 \text { years; site visits }\end{array}$ & $\begin{array}{l}\text { **IDP - achievement } \\
\text { data provided and } \\
\text { reviewed in text }\end{array}$ \\
\hline Same as above & $6,7,8$ & $\begin{array}{l}\text { Key Renaissance } \\
\text { Middle School } \\
\text { Indianapolis, IN }\end{array}$ & 165 & Since 1993 & $\begin{array}{l}\text { following phone } \\
\text { interview - classroom } \\
\text { observations and } \\
\text { teacher and student } \\
\text { interviews. }\end{array}$ & $\begin{array}{l}\text { **IDP - achievement } \\
\text { data provided and } \\
\text { reviewed in text }\end{array}$ \\
\hline
\end{tabular}

**IDP $=$ Insufficient data provided for effect size computation 
TABLE 3 (continued)

Studies of Multiple Intelligence Instructional Approaches in Secondary School Classrooms

\begin{tabular}{|c|c|c|c|c|c|c|}
\hline Article & Grades & Location & Sample size & Duration & Design & Effect Sizes \\
\hline Same as above & $9,10,11,12$ & $\begin{array}{c}\text { Mountlake Terrace } \\
\text { High School } \\
\text { Mountlake Terrace, } \\
\text { WA }\end{array}$ & 1,865 & Since 1990 & Same as above & $\begin{array}{l}\text { **IDP - achievement } \\
\text { data provided and } \\
\text { reviewed in text }\end{array}$ \\
\hline Same as above & $9,10,11,12$ & $\begin{array}{c}\text { Lincoln High School } \\
\text { Stockton, CA }\end{array}$ & 2,600 & Since 1990 & Same as above & $\begin{array}{l}* * \text { IDP }- \text { achievement } \\
\text { data provided and } \\
\text { reviewed in text }\end{array}$ \\
\hline Anderson, 1998 & 7,8 & $\begin{array}{l}\text { Two Unnamed } \\
\text { Schools in Same } \\
\text { Illinois District }\end{array}$ & $\begin{array}{c}100 \\
(\text { Site A \& B) }\end{array}$ & 1 year & $\begin{array}{l}\text { Quasi-experimental } \\
\text { design. Compared pre- } \\
\text { and post-test scores on } \\
\text { teacher assessments. }\end{array}$ & $\begin{array}{l}\text { **IDP }- \text { achievement } \\
\text { data provided and } \\
\text { reviewed in text }\end{array}$ \\
\hline
\end{tabular}

**IDP = Insufficient data provided for effect size computation 
TABLE 3 (continued)

Studies of Multiple Intelligence Instructional Approaches in Secondary School Classrooms

\begin{tabular}{|c|c|c|c|c|c|c|}
\hline Article & Grades & Location & Sample size & Duration & Design & Effect Sizes \\
\hline Ford, 2000 & 7 & $\begin{array}{c}\text { Unnamed } \\
\text { Midwestern U.S. } \\
\text { Junior High School }\end{array}$ & 93 & 1 year & $\begin{array}{l}\text { Quasi-experimental } \\
\text { design. Compared pre- } \\
\text { and post-test scores on } \\
\text { Iowa Test of Basic } \\
\text { Skills. }\end{array}$ & $\begin{array}{l}\text { Reading }-0.505 \\
\text { Social Studies } 0.460 \\
\text { Math Comp. } 0.989 \\
\text { Math Total } 0.473 \\
\text { Language } 0.383\end{array}$ \\
\hline
\end{tabular}




\section{Cases 1-4 - Kornhaber, Fierros, \& Veenema (2004) [Project SUMIT] and}

\section{Campbell \& Campbell (1999)}

The first four cases selected for inclusion in this research synthesis are components of a larger study carried out by Kornhaber, Fierros, \& Veenema, researchers closely linked to Howard Gardner and his Project Zero research group at Harvard University Graduate School of Education. Gardner articulately introduces their work and gives his nod of approval to their philosophical and methodological approaches.

Mindy Kornhaber and her colleagues, Ed Fierros and Shirley Veenema (whom I'll dub the Kornhaber trio), display a deep understanding of the theory of multiple intelligences. I have worked alongside Mindy for well over a decade; she understands the theory extremely well, and she has made valuable contributions to its current version. Equally important, the Kornhaber trio began their study with no particular ax to grind. Instead, they elected to study forty-one diverse schools, each of which had at least three years of experience working with MI ideas. The trio surveyed these schools carefully, interviewing key personnel and collecting qualitative data and information on student outcomes. They identified the features that characterize effective MI schools. And in this book, they present their findings... (p. xii)

This introduction is a major inducement to focus a great deal of attention on "the Kornhaber trio." Gardner's approval of their research and his voucher for the study's validity should carry great weight. Proceeding from an investigative, descriptive, qualitative approach, the "trio" seeks to identify and explain phenomena, not to push an 
ideological agenda. This aspect makes the Kornhaber et al. study quite notable; a number of studies in the multiple intelligences literature attempt to advocate (or oppose) a certain means of implementation as the only way or with the caveat that a particular approach is superior with little basis in fact. That each school included in the Kornhaber et al. study had at least three years of multiple intelligences implementation experience also increases the validity of the study, and should lead researchers and practitioners to focus greater attention on their methodology and instructional approach. In the Preface to their work, Kornhaber et al. (2004) claim that

...this is the only book about implementing MI based on a national investigation of diverse schools that associate MI with improvements for students. Most other books about MI are based on the experiences of a single teacher, school, or staff developer. In contrast, this book identifies approaches that are successful across particular classrooms, schools, and student populations. Thus, it presents a powerful, research-driven description of effective practices involving MI... (p. xiv)

Based on the work of this researcher in the literature survey process, this assertion proves true. The only other work that comes close in this regard is Campbell \& Campbell (1999). The Kornhaber trio proceeds to give their "pedigree" and describe the nature of their work. It is notable that their approach and their work is closely tied to Howard Gardner.

...this book was developed by investigators who have worked for many years at Project Zero, the research group at Harvard's Graduate School of Education that has been Howard Gardner's organizational base since 
1967. This book therefore draws deeply on the best ideas about multiple intelligences, learning, and school development as well as on the work of very talented practitioners who have shared their ideas with us. (p. xv)

For the purposes of this synthesis, Kornhaber et al. (2004) and Campbell \& Campbell (1999) will be linked. Four of the schools included in the Kornhaber trio's more global Project SUMIT study are profiled independently in the work of Campbell et al. (1999). Aggregated quantitative data from Project SUMIT is provided in Kornhaber et al. (2004) while individual, building-level data is provided in Campbell \& Campbell (1999). It is incumbent upon the researcher to point out that in some cases, insufficient data is provided for calculating effect size statistics for Project SUMIT participant schools. In those cases, Slavin (1995) is instructive: "Studies that meet standards of germaneness and methodological adequacy but do not yield effect size data should be discussed on the same basis as those that do yield effect size data" (p. 16).

\section{Project SUMIT (Cases One through Four) Citations}

Campbell, L. \& Campbell, B. (1999). Multiple intelligences and student achievement: success stories from six schools. Alexandria, VA: Association for Supervision and Curriculum Deve lopment.

Kornhaber, M.L., Fierros, E.G., \& Veenema, S.A. (2004). Multiple intelligences: best ideas from research and practice. Boston, MA: Allyn \& Bacon. 


\section{Project SUMIT Aggregate Demographic Data (Cases One through Four)}

Figure 2. Schools Participating in SUMIT: Socioeconomic Status of the School

\section{Population}

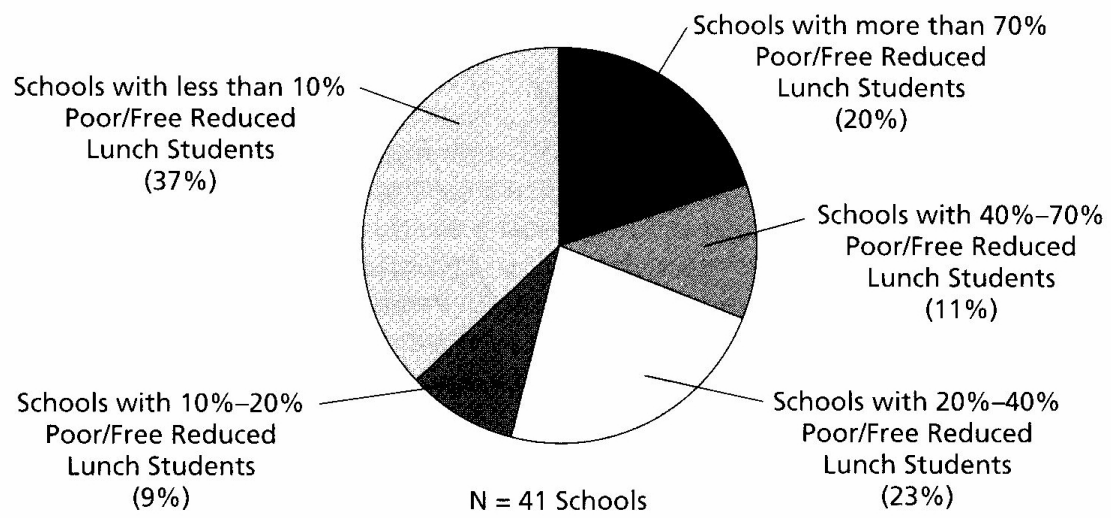

(Kornhaber, Fierros, \& Veenema, 2004, p. 12)

Figure 3. $\quad$ Schools Participating in SUMIT: Race/Ethnicity of the School Population

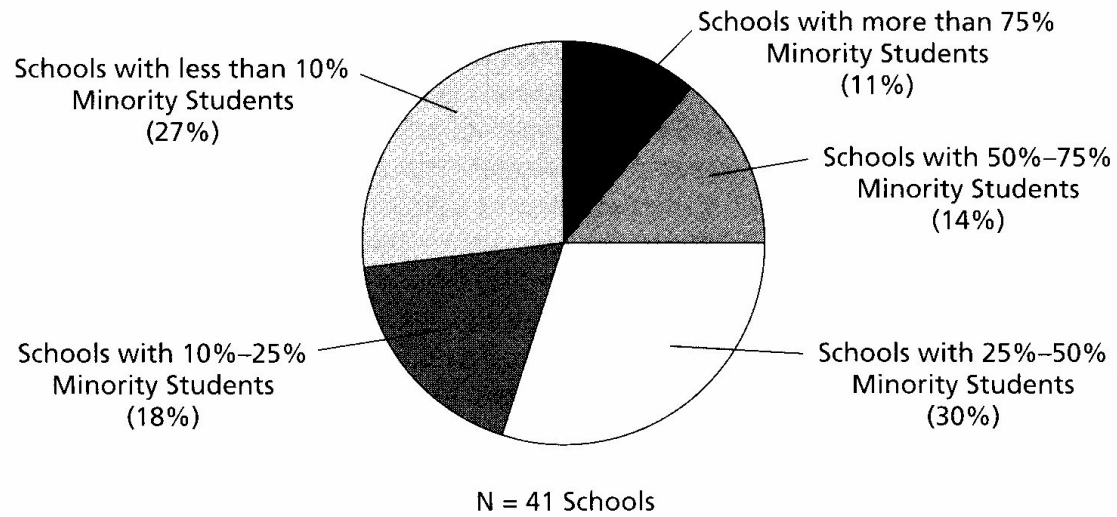

(Kornhaber, Fierros, \& Veenema, 2004, p. 12) 


\section{Case 1 - Skyview Junior High School - Bothell, Washington}

\section{Population}

Skyview Junior High is a large suburban school that houses $7^{\text {th }}, 8^{\text {th }}$, and $9^{\text {th }}$ grade students. The student body numbers approximately nine hundred students. Approximately ninety students, roughly ten percent of the student body, are on the free and reduced lunch program.

\section{Instruction and Assessment}

Planned throughout 1991 and opened in September 1992, multiple intelligence theory forms the basis for Skyview's educational mission and curriculum. In addition to the core academic classes, Skyview allows its students to choose elective classes that meet on a daily basis. These "acceleration class" electives are designed so that students can fully develop their intelligences. Initially, a modified student schedule by grade level and a common planning time for teachers allowed for these elective classes. From the 1998-99 school year onward, these acceleration activities were rescheduled for after-school hours, at the students' requests.

The school's forty-three teachers are teamed on an interdisciplinary basis (English, math, science, and social studies) and teach grade level "learning 
communities" of students. The school takes a blended approach to assessment. Traditional teacher-made assessments and performance-based assessments are the two major means of assessment at Skyview. There is no particular multiple intelligences-based instructional planning strategy or lesson planning technique at Skyview. Teachers fit the content to whichever of the intelligences it best naturally fits. Interdisciplinary units play a large role at Skyview. Each year, the interdisciplinary teacher team evaluates their grade level's performance and adapts their curriculum and teaching methods to target any deficiencies.

\section{Research Findings}

Prior to 1998, eighth grade students at Skyview scored approximately twenty percentage points higher than their state and national contemporaries on the Comprehensive Test of Basic Skills (CTBS), a state-mandated exam proctored each October to students in grades four and eight. This exam was replaced with the Washington Assessment of Student Learning (WASL), a standardized performance-based exam. Table 4 contrasts the performance of Skyview eighth graders on the WASL with the performance of all Washington state students on the WASL. Skyview students outperformed their peers statewide by at least ten percent in every subject area tested by means of the WASL. 
Table 4. Achievement of Skyview Junior High School Students and their Peers on the WASL Tests

\begin{tabular}{|l|r|r|}
\hline \multicolumn{1}{|c|}{ Subject Area Tested } & $\begin{array}{c}\text { Percentage of Washington } \\
\text { state students meeting the } \\
\text { WASL standards }\end{array}$ & $\begin{array}{c}\text { Percentage of Skyview } \\
\text { students meeting the WASL } \\
\text { standards }\end{array}$ \\
\hline Reading & $38.4 \%$ & $61.5 \%$ \\
\hline Writing & $31.3 \%$ & $48.6 \%$ \\
\hline Math & $20.1 \%$ & $36.6 \%$ \\
\hline Listening & $80.2 \%$ & $92.6 \%$ \\
\hline
\end{tabular}

(Adapted from Campbell \& Campbell, 1999, p. 50) 


\section{Case 2 - Key Renaissance Middle School - Indianapolis, Indiana}

\section{Population}

Key Renaissance Middle School is a part of the Key Learning Community. In 1993, the middle school program was added to an established Kindergarten through $5^{\text {th }}$ Grade program. Key Renaissance has a student population of 165 sixth through eighth grade students. Approximately eighty students (roughly fifty percent of the student body) are composed of minority students. Approximately seventy students (roughly forty- five percent of the student body) are enrolled in the free and reduced lunch program.

\section{Instruction and Assessment}

Key Renaissance Middle School was founded in 1993 and serves as a magnet school for the district; however, there are no academic requirements for admission. Students are chosen randomly by means of a lottery. The school is an outgrowth of the Key Learning Community, the nation's first elementary school to be founded on Gardner's theory of multiple intelligences. However, less than fifty percent of the middle school students at Key matriculate from Key's elementary program. 
A thematic program dedicated to all eight of Gardner's identified intelligences is the primary instructional program at Key Renaissance Middle School. This program provides equal instructional time (200 minutes per week) to activities targeted at each of Gardner's eight intelligences. Each of Key Renaissance Middle School's ten teachers is viewed as an “intelligence specialist." The teachers work collaboratively in applying multiple intelligences theory in each classroom through an advisory program, a weekly schedule, school-wide themes, and perpetual professional development. Each student takes classes in English, German, instrumental music, math, science, visual arts, physical education, and geography/history. Volunteers from the community periodically offer elective classes and other mentored experiences. Campbell \& Campbell (1999) identify desired multiple intelligences learning outcomes for each student.

Upon graduation, each Key student will

- communicate clearly in written form,

- be verbally articulate in two languages,

- sing or play a musical instrument proficiently,

- use math and logic in applied areas,

- use technology as a tool for inquiry and communication,

- recreate the three-dimensional world through the visual or practical arts,

- be physically fit, 
- select an applied area for inquiry, reflection, and apprenticeship,

- participate in stewardship activities with nature,

- express a capacity to care about global issues, [and]

- participate in groups and organizations in the larger community. (pp. 52-53)

Key Renaissance Middle School relies heavily on videotaped projects that employ many different modes of presentation These taped projects allow students, teachers, and parents to gauge development and growth over time. Other means of assessment typically employed at Key Renaissance Middle School also include performance-based assessment and portfolio assessment. A primary focus of assessment is engaging students in reatworld tasks. The school staff also created its own student achievement profile based on MI theory entitled the Pupil Progress Report. According to Campbell \& Campbell (1999),

Students are assessed in the eight intelligences through three criteria:

1. Progress refers to the rate of growth in an intelligence, which can be slow, steady, or rapid.

2. Participation describes whether a student is intrinsically or extrinsically motivated or passive or disruptive in class.

3. Performance refers to a developmental continuum. (p. 60) These Pupil Progress Reports are generated quarterly and based on input from from all of the student's teachers. Mandatory student, parent, and teacher 
conferences allow all stakeholders an opportunity to communicate and discuss progress.

\section{Research Findings}

Currently, students at Key Renaissance Middle School achieve above grade level in all subject areas tested on both state and national tests. This has not always been the case. From its inception in 1993 until 1997, approximately fifty percent of Key students scored average on the Indiana Statewide Testing for Educational Progress (ISTEP). According to Campbell \& Campbell (1999), school staff members claim that this lackluster performance was due to students adjusting to the school's instructional techniques and assessment methods along with formatting revisions on the ISTEP.

Student achievement scores improved in 1998; Table 5 demonstrates $6^{\text {th }}$ and $8^{\text {th }}$ grade subject area scores on the 1998 ISTEP. Similar achievement gains have been demonstrated on the California Test of Basic Skills (CTB); in 1998,

sixth, seventh, and eighth graders scored at least one year above grade level on the CTB. 
Table 5. Key Learning Community's Scores on 1998 Indiana Statewide Testing for Educational Progress

\begin{tabular}{|l|r|r|r|}
\hline $\begin{array}{c}\text { Grade and Number } \\
\text { of Students }\end{array}$ & $\begin{array}{c}\text { Grade Equivalent } \\
\text { Reading Score Total }\end{array}$ & $\begin{array}{c}\text { Grade Equivalent } \\
\text { Language Score } \\
\text { Total }\end{array}$ & $\begin{array}{c}\text { Grade Equivalent } \\
\text { Math Score Total }\end{array}$ \\
\hline $6^{\text {th }}$ Grade Students \\
$(\mathrm{N}=51)$
\end{tabular}

(Adapted from Campbell \& Campbell, 1999, p. 61) 


\section{Case 3 - Mountlake Terrace High School - Mountlake Terrace, Washington}

\section{Population}

Mountlake Terrace High School was founded in 1961 and upon moving to a new building in 1991, began using MI theory in classroom planning, instruction, and assessment. The population at Mountlake Terrace High School is approximately 1,865 students in grades $9-12$. The school is situated in a suburban setting. Approximately 465 students (roughly twenty-five percent of the student body) are minority students. Approximately 245 students (roughly fifteen percent of the student body) are enrolled in the free and reduced lunch program.

\section{Instruction and Assessment}

The instructional staff at Mountlake Terrace includes eighty-three teachers, four administrators, and a variety of other support personnel. Classroom instruction and activities are firmly grounded in multiple intelligences theory. A number of assessments are project-based. Performance-based assessments are employed in all classes. Students are grouped based on their level of understanding. Hallmarks of Mountlake Terrace's instructional program include professional development for teachers, changes in pedagogical practices, realworld assessment tasks, program restructuring, and reconfiguring of the school. The school is configured as a collection of multi-age groupings with students 
assigned to one of three groups (based on their level of understanding). Campbell \& Campbell (1991) delineate and describe these three levels of understanding. At the entry level, students are expected to develop basic skills in essential areas such as communications, math, science, and technology. The second or core level builds upon the basic skills by extending student knowledge in what would be considered the 'traditional' curriculum of most high school programs. At the third or application level, students must prepare a final, public presentation of a self-directed project that exemplifies their individual talents, interests, and accomplishments. (p. 67) Students are always viewed as progressive works-in-progress. As a requisite for graduation, students must complete a high-stakes "application project" that employs multiple modalities. Educators at Mountlake Terrace have devised a list of competencies that each student will demonstrate by the time of their graduation. This list of competencies is illustrated in Figure 4. 
Figure 4. Mountlake Terrace High School Graduation Competencies.

\section{Mountlake Terrace High School Graduation Competencies}

- Understand one's relationship to the global environment.

- Understand human relations in interpersonal and family settings.

- Gather, select, interpret, organize, use, and evaluate information.

- Develop a broad knowledge of human civilization.

- Develop lifelong programs for the mind and body.

- Communicate in a variety of different formats to different audiences.

- Develop and apply critical thinking skills.

- Develop, articulate, and act upon one's value system.

- Use self-assessment to determine one's educational progress, plan future growth, and become a self-directed learner.

- Prepare for the work world by developing an educational plan.

- Express one's self creatively through various art forms, developing a sense of aesthetics.

- Understand, evaluate, and use a wide range of technological tools.

- Solve multi-step mathematical problems in a variety of ways.

- Demonstrate knowledge of economic systems on a personal, community, state, national, and global level.

- Read, analyze, and interpret various written materials.

- Demonstrate literacy and knowledge of basic methods, terms, and concepts in the sciences.

(Adapted from Campbell \& Campbell, 1999, p. 68) 


\section{Research Findings}

Mountlake Terrace students score higher than peers in English, math, and social studies on the Curriculum Framework Assessment System (CFAS). The CFAS is a state-mandated assessment for eleventh grade students in the state of Washington. Scores earned by Mountlake Terrace students have consistently improved. The school has moved from below district averages to above district averages. Mountlake Terrace's math scores on the CFAS are ten percentage points above the state norm. In fact, Mountlake Terrace was one of only nine schools to show a continuous upward trend in math scores on the CFAS.

Students at Mountlake Terrace also perform higher than their state and national peers on the Scholastic Aptitude Test (SAT). From 1994 to 1996, the average student score on the math portion of the SAT rose from 477 to 519 . During the same time period, the average student score on the verbal section of the SAT rose from 430 to 501. 


\section{Case 4 - Lincoln High School - Stockton, California}

\section{Population}

Lincoln High School has a student population of approximately 2,600 students. The suburban school educates students in grades 9-12. Approximately 1,300 students (roughly fifty percent of the student body) are minority. Approximately twenty-five percent of the students (roughly 650 students) are enrolled in the free and reduced lunch program. Roughly thirteen percent of Lincoln's students have limited English proficiency. Student daily attendance averages ninety-seven percent.

\section{Instruction and Assessment}

The school staff is comprised of 122 teachers, seven administrators, four counselors, and the requisite support personnel. MI-based instructional strategies that employ a wide array of learning modalities are employed throughout the school. Academic offerings include business and applied arts, English, foreign language, multilingual programs, math, science, social science, physical education, non-departmental programs, and visual and performing arts. Teachers are given a great deal of freedom in determining curriculum and instructional methodologies. Course offerings also include a variety of "Integrated Studies" classes that are taught from an interdisciplinary approach. Two-teacher teams 
instruct these classes during back-to-back class periods. Long-term research assignments are employed in a number of the Integrated Studies courses. Assessment methods are generally oriented toward performance-based and/or project-based measures. Students are given the opportunity to reflect upon and assess a great deal of their own work. They are also given the opportunity to work with their peers in group learning activities on a regular basis.

\section{Research Findings}

Lincoln High students scored higher on the 1997-98 administration of the Stanford Test of Academic Skills, fourth edition(STAS-4) than students from any other school in the county. This notable accomplishment is overshadowed by the fact that Lincoln students scored in the fifty-fifth percentile when compared to a national norms group. Lincoln school administrators intend to use the 1997-98 STAS-4 data as a baseline for improvement. Campbell \& Campbell (1999) note that Lincoln High administrators claim that Lincoln students outscore district and state peers on SAT and ACT tests. However, there is no data that verifies this claim. Ninety-seven percent of Lincoln High School students graduate and ninety percent of Lincoln High graduates matriculate to either two- or four-year colleges. 


\section{Limitations of Project SUMIT and Campbell \& Campbell Studies}

Another high school was noted in Kornhaber et al. (2004) as a participant in the Project SUMIT study - Champlain Valley High School in Hinesburg, Vermont. While the school was noted, no disaggregated data related to the school was presented by Kornhaber et al. In addition, Champlain Valley High School was not one of the schools profiled in Campbell \& Campbell (1999). The failure to provide additional insight into the rare occurrence of a multiple intelligences-based high school program limits the scope of these research studies.

While it is apparent that the researchers spent a great deal of time investigating the implementation, application, and assessment philosophies and methodologies in Cases 1-5, there are some weaknesses in how results from these studies are presented. The Project SUMIT researchers provided only aggregate data for all forty-one schools included in their study. The increased value of a larger sample size is both a blessing and a curse. It allows for a greater net to be cast and for MI-based educational applications to be evaluated on a larger scale. However, the lack of disaggregated, individual school building data makes substantive analysis of the role of MI in student academic achievement difficult to assess. By the same token, the inverse is true of the Campbell \& Campbell study. Both the SUMIT researchers and Campbell \& Campbell limit the effectiveness and generalizability of their work by failing to provide both global and disaggregated data. Providing both forms of data would allow for a more substantive analysis of the effectiveness of multiple intelligences-based educational practices. 
Insufficient data was provided in all four Project SUMIT/Campbell \& Campbell (1999) cases to allow for the computation of effect size. Without the ability to compute ES statistics for these four cases, it is not possible to adequately quantify academic achievement in these multiple intelligences-based educational environments. However, it is important to remember Slavin's contention regarding the absence of data allowing for the calculation of ES statistics. "Studies that meet standards of germaneness and methodological adequacy but do not yield effect size data should be discussed on the same basis as those that do yield effect size data" (Slavin, 1995, p. 16).

Several of the schools profiled by Campbell \& Campbell received grants, policy waivers, release days, and relaxation of oversight rules (e.g., Mountlake Terrace High School and Lincoln High School) to allow for their incarnation of multiple intelligences theory. These favorable conditions would not exist in a large number of school environments, and as such, limit the value of this research to particular populations under exceptional conditions. 


\section{Case 5}

Anderson, V.B. (1998). Using multiple intelligences to improve retention in foreign language vocabulary study. Master's Action Research Project, St. Xavier University and IRI/Skylight, United States -- Illinois. (ERIC Document Reproduction Service No. ED424745).

\section{Purpose}

The purpose of this study was to increase student retention of foreign language vocabulary and to increase student academic achievement in foreign language classes through the use of MI-based instructional methodologies.

\section{Population}

The population of this study consists of eighth grade Latin students from two unnamed suburban middle schools within the same school district. Anderson dubbed these schools "Site A" and "Site B". Both student populations are primarily white, middle-class students with less than ten percent of students in each school coming from economically disadvantaged families. Total enrollment at Site A is 883 students, while Site B has a total enrollment of 890 students. Several staff members (including Anderson) travel between and teach at both Site A and Site B. 


\section{Research Design}

The design of this study was quasi-experimental; the study was carried out the same way at Sites A and B. Following a period of MI-based instructional activities, the progress of eighth grade Latin students were assessed by means of weekly teacher-made vocabulary quizzes. Other assessment practices included reviewing previous scores, comparing previous scores with current scores, and teacher observation.

Students were divided into four groups based on their most dominant intelligence profile. No information was provided in the study regarding profile of intelligence assessments. The groups were based on the following intelligences: bodily-kinesthetic, linguistic, interpersonal, and spatial. (Anderson believed these intelligences best fit for successful implementation in the foreign language classroom.) Each week, every group devised two learning activities based on their dominant intelligence for a teacher-assigned set of vocabulary words. Following these instructional activities, identical teacher-made vocabulary quizzes were administered at both sites. 


\section{Research Findings}

Results of this study indicate that MI-based instructional approaches can be an effective means of improving student retention of foreign language vocabulary and academic achievement (see Table 6) on teacher-made quizzes.

Table 6. Comparison of Current and Past Student Vocabulary Quiz Scores

SITE A

\begin{tabular}{|l|r|r|}
\hline & Current 8 $^{\text {th }}$ Grade Student Scores & Past 8 $^{\text {th }}$ Grade Student Scores \\
\hline Quiz 15 & $70.8 \%$ & $57.1 \%$ \\
\hline Quiz 16 & $75.1 \%$ & $71.3 \%$ \\
\hline Quiz 17 & $80.0 \%$ & $64.8 \%$ \\
\hline Quiz 18 & $77.3 \%$ & $73.8 \%$ \\
\hline
\end{tabular}

SITE B

\begin{tabular}{|l|r|r|}
\hline & Current 8 $^{\text {th }}$ Grade Student Scores & Past 8 $^{\text {th }}$ Grade Student Scores \\
\hline Quiz 15 & $79.3 \%$ & $56.8 \%$ \\
\hline Quiz 16 & $83.3 \%$ & $69.2 \%$ \\
\hline Quiz 17 & $90.9 \%$ & $52.6 \%$ \\
\hline Quiz 18 & $94.5 \%$ & $65.3 \%$ \\
\hline
\end{tabular}

(Adapted from Anderson, 1998, p. 32-33) 


\section{Limitations of Study}

The greatest limitation of this study was that the researcher used scores from previous years' classes as a pre-test and used the current group to demonstrate treatment effects. In this situation, no pre-testing was conducted (or at least none was reported) on the experimental group in the study. While this may have proven useful to the researcher in her educational setting, this deficiency strongly diminishes the validity of the study's outcomes.

The MI-based instructional methodologies used as the treatment in this study were devised by students. There is no documentation in the study proving students were adequately prepared for this task in that they received very little instruction in multiple intelligences theory or pedagogy. Allowing students to introduce treatments on the basis of their preferences and then carry out those treatments diminishes researcher control of the experiment. This reduces validity of the study because of the wide array of instructional practices introduced and carried out by students.

Another major limitation of this study was that it involved only one teacher in a classroom at two junior high schools in the same school district. This limited setting does not allow for substantial generalization of this study's findings to other settings. 


\section{Case 6}

Ford, D.M. (2000). A study of the effects of implementation of multiple intelligence techniques and integrated thematic instruction on seventh-grade students. Ed.D. dissertation, Saint Louis University, United States -- Missouri. Retrieved August 17, 2004, from ProQuest Digital Dissertations database. (Publication No. AAT 9973345).

\section{Purpose}

The purpose of this quasi-experimental study was to test the effectiveness of integrating multiple intelligences techniques and Integrated Thematic Instruction (ITI) [an instructional strategy compatible with MI theory] in improving academic achievement of seventh grade students in a junior high school.

\section{Population}

The ninety-three students who participated in this study attend a junior high school located on an unnamed military base in Kansas. This base houses the Command and General Staff College that provides training and experience to military personnel aspiring to lead the Army's ranks. The school is only open to 
dependents of military or civilian personnel assigned to or employed by the base. Approximately thirty percent of the student body is composed of minority students. A large part of the school body is transient because military parents and their children are usually transferred after one year. These factors make the study's population significantly different from the average American junior high school.

\section{Research Design}

Fourty-nine students comprised the control group while the remaining fourty-four seventh grade students comprising the study sample were taught using the multiple intelligences-compatible ITI instructional approach. Students' schedules were systematically altered by the school's counselor to balance the control and experimental groups in terms of gender, ethnicity, and parent military rank. MI-based ITI instruction was offered in math, social studies, and English classes. This study employed a quasi-experimental design. The Iowa Test of Basic Skills (ITBS) was employed as the pre- and post-test in relation to the MIbased instructional treatment. The independent variables are defined in this study as seventh grade students exposed to instruction based on MI and ITI (the experimental group) and seventh grade students exposed to traditional classroom instruction (the control group). The dependent variables are the improvements made from pre- to post-test scores on the ITBS assessment. 


\section{Research Findings}

According to Ford, the ITBS has reliability coefficients of 0.87 for all component sub-tests and 0.98 for all core total and composite average values total test scores. A national norms groups and appropriate psychometric properties of the ITBS drove Ford to determine that it would be employed as the measure of effectiveness in this study.

This study provided sufficient data to allow for the computation of effect size statistics that demonstrate and at least partially quantify the treatment effects of MI-based ITI instruction. A -0.505 effect size for reading comprehension demonstrates that students in the traditional instruction (control) group had moderately greater achievement gains compared to students in the MI/ITI (experimental) group. Students exposed to MI/ITI instruction scored demonstrated moderate gains over the students in a traditional instructional setting in social studies $(\mathrm{ES}=0.46)$, language $(\mathrm{ES}=0.383)$, and the total mathematics score $(E S=0.473)$. The experimental group showed a very significant academic increase over the control group in the area of mathematical computation with an effect size of 0.989 . 


\section{Limitations of Study}

One limitation of this study was the relatively small sample size $(\mathrm{N}=93)$. This small sample size makes ascertaining significant statistical relationships difficult. The investigator also allowed teachers the freedom to implement MI instructional strategies as they chose, with no standardized methodological approach. While this is congruent with multiple intelligences theory, it does not allow the researcher to limit variance and increase the validity of his study.

In addition, teachers included in this study were volunteers with approximately ten days of professional development training in multiple intelligences theory. The greatest limitations of this study include its targeted population and limited teacher participation. Since the students in this study attend a Junior High open only to children of military personnel, the results of the study are not easily generalizable to other settings. Only three teachers participated in this study. 


\section{Chapter IV: Summary and Conclusions}

This study allows for several conclusions:

1. A very limited amount of research focusing on the relationship of multiple intelligence instructional approaches and student achievement indicators in secondary school classrooms exists;

2. Instances of multiple intelligence instructional approaches vary widely in methodology and implementation but demonstrate a fairly consistent philosophical approach; and

3. The studies included in this research synthesis failed to prove causation in the relationship of multiple intelligence instructional approaches and student achievement indicators in secondary school classrooms.

While the limited evidence and limited scope of the topic in the extant literature failed to show causation on a quantitative basis, substantial evidence exists showing that multiple intelligences theory contributes positively to student learning and development. Fortynine percent of Project SUMIT participant schools associate MI with improved standardized test outcomes (see Figure 6). 
Figure 5. Standardized Test Outcomes Reported by Educators in Schools

Participating in SUMIT.

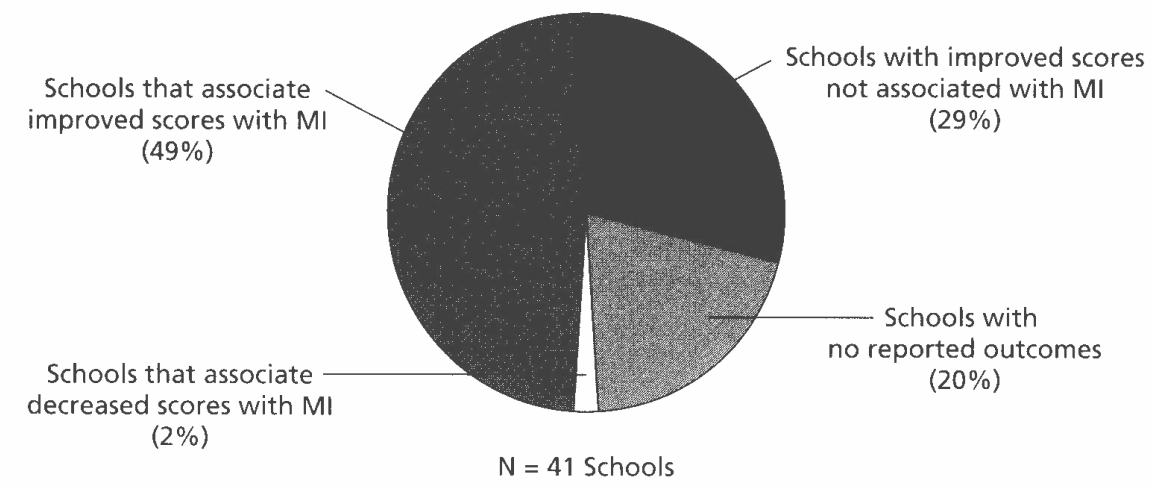

(Kornhaber, Fierros, \& Veenema, 2004, p. 13)

Several researchers have noted the dearth of research related to multiple intelligences-based secondary educational programs. Acknowledging this lack of research, Hickey (2004) states, "Few examples describing classroom teachers' design and implementation of MI-based instructional units are found in the literature. Even fewer examples exist depicting MI-based units used in the middle grades classroom" (p. 86). Campbell \& Campbell (1999) note, "While MI theory has been embraced by many elementary and some middle schools, acceptance is rarer in high schools" (p. 63). This researcher concurs. Very few examples of multiple intelligences-based instruction and implementation at the high school level are in the literature. This lack of quantity (essentially a small samp le size) severely limits the validity and usefulness of this study.

An implicit belief in the educational community seems to be that "MI is better for the lower grades, then things change when the academics get tougher in high school." 
Armstrong (2000) argues that puberty does not disconnect students from their multiple intelligences and that students should be taught high school subject content using their multiple intelligences. This is an interesting corollary to the lack of secondary-school level multiple intelligences research and a forceful argument in favor of greater implementation of MI-based instructional practices in secondary school classrooms.

One of the reasons that educators have gravitated to this theory is that it acknowledges and values the uniqueness of each learner. By focusing on the abilities and cognitive development of the individual, MI increases the educational equity afforded to all students. The current accountability movement strives for uniformity for the sake of standardization and comparison. Indeed, Eisner (2004) states,

As attractive as such an aspiration might be [educational equity], it is not the kind of aim that currently drives our schools. We are much more concerned with standardization and homogenization than with the cultivation of variance in a group's performance. Our anxieties about the performance of our students in our schools lead to remedies that stress uniformity of content, uniformity of assessment procedure, [and] uniformity of outcome" (p. 33).

Some researchers and some practitioners acknowledge the value of multiple intelligences theory. Chen (2004) argues that "The value of MI theory has been clearly established by its many successful applications in the field" (p. 22). While the proof of any theory lies in its quantification, Chen (2004) contends that, "Because MI theory is 
based on the conception of human cognitive functioning in diverse real-life situations, its scientific establishment is grounded in empirical data that describe the functioning of multiple abilities in diverse situations" (p. 18). Chen (2004) proceeds to argue that, "If we limit studies by relying on a single standard for the acceptable measurement of intelligence, our understanding of this most central capacity of human beings will be significantly restrained" (p. 19).

The current standards movement, driven by high-stakes testing and other forms of standardized assessment, praises school improvement initiatives that increase student achievement. Howard Gardner (1997b) praises multiple intelligence theory as a catalyst for school improvement and goes a step further by providing three benefits of using MI in schools. “...MI can be an extremely useful tool - or better, partner - in the process of creating excellent schools. It can aid in a variety of missions from engaging more children to encouraging deeper understanding to preparing students for work" (pp. 2021).

The literature shows that there seems to be a great deal of practical value in multiple intelligences theory. According to Chen (2004), "MI theory has given them [teachers and parents] more accurate perceptions of children's intellectual potentials and more specific methods for supporting and developing these potentials" (p. 20). One reason cited by teachers for adopting multiple intelligences theory was that it conformed to their classroom experiences. Eisner (2004) concurs with this rationale. "There is something socially right about the idea that children and adolescents should be given an 
opportunity to shine in classrooms in which their particular strengths can be nurtured and made public"(p. 33).

Slavin (1986) argues that a best-evidence synthesis should create and support conclusions based on the best available evidence, "or in some cases may conclude that the evidence currently available does not allow for any conclusions." This study is inconclusive. It is limited by the meager quantity of research focusing on multiple intelligences in secondary school classrooms. The cases that met the criteria for inclusion were either focused on too wide a target audience or too narrow an application.

The SUMIT studies, along the other included studies, met the criteria for germaneness and methodological approach, but did not contain the necessary information to compute effect size statistics. This inability to quantify the effects of multiple intelligences-based instructional approaches on indicators of student achievement in secondary school classrooms is a significant impediment to this study.

While the inconclusiveness of this study is frustrating to the researcher, it is important to note what Robert Slavin said regarding educational research. "The ultimate beneficiaries of education research must be children, not the researchers themselves. Enlightened educators look to education research for well-founded evidence to help them do a better job with the children they serve" (Slavin, 2004, p. 27). 
While claims of success with multiple intelligences implementation are generally presented in the literature in narrative or qualitative form without quantitative evidence, Gardner, quoted in Kornhaber, et al. (2004), does not even claim that classroom practices derivative of MI theory must be successful. He also acknowledges the lack of data regarding MI-based instructional practices. "Much as I would like to, I cannot simply assert that MI theory is right, or that MI practices are destined to succeed. We do not have enough data to make such claims..." (p. xiii). Gardner recognizes the need for further research in the educational application of multiple intelligences theory.

This research synthesis has demonstrated the need for further, more focused quantitative research on MI instructional approaches in secondary school classrooms. Until these studies commence and their results become available, researchers and practitioners attempting to ascertain the value of applying MI-based principles and practices in the classroom must judge the theory's value for themselves until more conclusive and more thoroughly documented evidence is presented. Recommended conditions for future research include:

(1) Consistent definitions of achievement and consistent usage of assessment instruments that genuinely measure academic achievement and individual profiles of intelligence;

(2) Appropriate professional development for practitioners;

(3) A standardized set of MI theory-based instructional practices; and

(4) Research studies in venues that have implemented MI for periods of time longer than one year. 
The discussion and debate regarding the utility and effects of multiple intelligences theory in the classroom is not likely to be settled in the near future. A key point in these discussions and debates is the way progress and achievement is measured. In some respects, the debate between advocates for traditional education and advocates for MI-based education is a microcosm of the larger struggle for improvement and accountability in American schools. Is the measurement of progress and achievement to be a high-stakes, standardized assessment or a developmental, individualized performance-based assessment?

In relation to MI theory and standardized testing outcomes, Latham (1997) says, Using standardized scores in isolation to quantify students' gains would have been antithetical to the whole purpose of the theory. A more appropriate question to ask is, Does multiple intelligence theory prove useful in the classroom? How people answer that depends on what they want to accomplish. If they simply want to improve test scores, multiple intelligences may work no better or worse than other theories. But if the goal is to reach as many students as possible, and to acknowledge, celebrate, and refine their talents, then multiple intelligences appears to hold great promise (p. 85).

While high-stakes assessments may be contrary to Gardner's wishes, the current educational context mandates such assessments. When described in Latham's terms, and based on this study, MI does appear to hold great promise in reaching a divergent group 
of students, encouraging their development, and preparing them for future occupations and avocations. 


\section{REFERENCES}

Anderson, V.B. (1998). Using multiple intelligences to improve retention in foreign language vocabulary study. Master's Action Research Project, St. Xavier University and IRI/Skylight, United States -- Illinois. (ERIC Document Reproduction Service No. ED424745).

Armstrong, T. (2000). Multiple intelligences in the classroom. 2nd ed. Alexandria, VA: Association for Supervision and Curriculum Development.

Armstrong, T. (1999). Seven kinds of smart: Identifying and developing your multiple intelligences. New York, NY: Penguin Putnam, Inc.

Armstrong, T. (2003). The multiple intelligences of reading and writing. Making the words come alive. Alexandria, VA: Association for Supervision and Curriculum Development.

Beam, K.L. (2000). A comparison of the theory of multiple intelligences instruction to traditional textbook-teacher instruction in social studies of selected fifth-grade students. Ed.D. dissertation, University of Sarasota, United States - Florida. Retrieved August 17, 2004, from ProQuest Digital Dissertations database. (Publication No. AAT 9957910).

Bouton, D.A. (1997). Operationalizing multiple intelligences theory with adolescent males. Ph.D. dissertation, Virginia Commonwealth University, United States Virginia. Retrieved August 17, 2004, from ProQuest Digital Dissertations database. (Publication No. AAT 9736790). 
Campbell, L. \& Campbell, B. (1999). Multiple intelligences and student achievement: Success stories from six schools. Alexandria, VA: Association for Supervision and Curriculum Development.

Campbell, L., Campbell, B., \& Dickinson, D. (1999). Teaching \& learning through multiple intelligences. Boston, MA: Allyn \& Bacon.

Checkley, K. (1997). The first seven... and the eighth. Educational Leadership, 55(1), $8-13$.

Chen, J. (2004). Theory of multiple intelligences: Is it a scientific theory? Teachers College Record, 106(1), 17-23.

Davies, P. (2000). The relevance of systematic reviews to educational policy and practice. Oxford Review of Education, 26(3-4), 365-378.

Davidson, J.E. (1990). Intelligence recreated. Educational Psychologist, 25(3-4), 337354.

Dobbs, V.R. (2001). The relationship between implementation of the multiple intelligences theory in the curriculum and student academic achievement at a seventh-grade at-risk alternative school. Ed.D. dissertation, Trevecca Nazarene College, United States -- Tennessee. Retrieved August 17, 2004, from ProQuest Digital Dissertations database. (Publication No. AAT 3027334).

Eisner, E.W. (2004). Multiple intelligences: its tensions and possibilities. Teachers College Record, 106(1), 31-39.

Feeney, M.O. (1999). The impact of Howard Gardner's theory of multiple intelligences on change in middle school language arts curriculum. Ed.D. dissertation, Seton Hall University, College of Education and Human Services, United States -- New 
Jersey. Retrieved August 17, 2004, from ProQuest Digital Dissertations database. (Publication No. AAT 9917995).

Fisher, EM. (1997). A cross case survey of research based on Howard Gardner's theory of multiple intelligences. Ph.D. dissertation, University of South Carolina, United States -- South Carolina. Retrieved August 17, 2004, from ProQuest Digital Dissertations database. (Publication No. AAT 9815503).

Ford, D.M. (2000). A study of the effects of implementation of multiple intelligence techniques and integrated thematic instruction on seventh-grade students. Ed.D. dissertation, Saint Louis University, United States -- Missouri. Retrieved August 17, 2004, from ProQuest Digital Dissertations database. (Publication No. AAT 9973345).

Franzen, R.J. (1999). Self-perceptions of multiple intelligences among students from a middle school in the Midwest. Ed.D. dissertation, University of South Dakota, United States -- South Dakota. Retrieved August 17, 2004, from ProQuest Digital Dissertations database. (Publication No. AAT 9958715).

Gardner, H. (1997a). An interview with Howard Gardner. Mindshift Connection: Multiple Intelligences. Tucson, AZ: Zephyr.

Gardner, H. (2004). Audiences for the theory of multiple intelligences. Teachers College Record, 106(1), 212-220.

Gardner, H. (1993a). Frames of mind: The theory of multiple intelligences. New York, NY: Basic Books.

Gardner, H. (1999a). Intelligence reframed: Multiple intelligences for the 21st century. New York, NY: Basic Books. 
Gardner, H. (1997b). Multiple intelligences as a partner in school improvement.

Educational Leadership, 55(1), 20-21.

Gardner, H. (1993b). Multiple intelligences: The theory in practice. New York, NY: Basic Books.

Gardner, H. (1999b). The disciplined mind: What all students should understand. New York, NY: Simon \& Schuster.

Gardner, H. (1991). The unschooled mind: How children think and how schools should teach. New York, NY: Basic Books.

Gibson, B.P. \& Govendo, B.L. (1999). Encouraging constructive behavior in middle school classrooms: A multiple-intelligences approach. Intervention in School \& Clinic, 35(1), 16-21.

Gooch, K.R. (2002). "I feel smart": The dynamic interaction between three learning theories, reading skills and conceptual understandings in an eighth-grade science action research study. Ed.D. dissertation, Fielding Graduate Institute, United States - California. Retrieved August 17, 2004, from ProQuest Digital Dissertations database. (Publication No. AAT 3072257).

Gutierrez, R., \& Slavin, R.E. (1992). Achievement effects of the nongraded elementary school: A best-evidence synthesis. Review of Educational Research, 62, 333376.

Hickey, M.G. (2004). “Can I pick more than one project?" Case studies of five teachers who used MI-based instructional planning. Teachers College Record, 106(1), 7786. 
Hoerr, T.R. (2000). Becoming a multiple intelligences school. Alexandria, VA: Association for Supervision and Curriculum Development.

Hoerr, T.R. (2003). It's no fad: Fifteen years of implementing multiple intelligences. Educational Horizons, 81(2), 92-94.

Johnson, S.E. (1996). Multiple intelligences: Seven keys to opening closed minds. NASSP Bulletin, 80, 29-35.

Kavale, K.A. (2001). Meta-analysis: A primer. Exceptionality, 9(4), 177-183.

Kornhaber, M.L. (2004). Multiple intelligence: From the ivory tower to the dusty classroom - but why? Teachers College Record, 106(1), 67-76.

Kornhaber, M.L., Fierros, E.G., \& Veenema, S.A. (2004). Multiple intelligences: Best ideas from research and practice. Boston, MA: Allyn \& Bacon.

Latham, A.S. (1997). Quantifying MI's gains. Educational Leadership, 55(1), 84-85.

Lazear, D. (1999). Eight ways of knowing: Teaching for multiple intelligences. Arlington Heights, IL: Skylight.

Lazear, D. (1994). Multiple intelligence approaches to assessment: Solving the assessment conundrum. Tucson, AZ: Zephyr Press.

Maddox, J.V. (2002). Teacher training in multiple intelligences strategies and cooperative learning structures to effect a change in the classroom. Ed.D. dissertation, Pepperdine University, United States -- California. Retrieved August 17, 2004, from ProQuest Digital Dissertations database. (Publication No. AAT 3078563). 
Martin, J.M. (1999). Assessment in multiple intelligences. Ed.D. dissertation, Loyola University of Chicago, United States -- Illinois. Retrieved August 17, 2004, from ProQuest Digital Dissertations database. (Publication No. AAT 9953785).

McGraw, R.L., Jr. (1997). Multiple intelligences theory and seventh-grade mathematics learning: A comparison of reinforcing strategies. Ph.D. dissertation, Georgia State University, United States -- Georgia. Retrieved August 17, 2004, from ProQuest Digital Dissertations database. (Publication No. AAT 9804390).

Muehlbauer, C.F. (2000). The effects of an arts-infused, multiple intelligences program on mathematical achievement. Ed.D. dissertation, Duquesne University, United States -- Pennsylvania. Retrieved August 17, 2004, from ProQuest Digital Dissertations database. (Publication No. AAT 9993766).

New American Standard Bible. (1995). Grand Rapids, MI: Zondervan Publishing House.

Nguyen, T.T. (2000). Differential effects of a multiple intelligences curriculum on student performance. Ed.D. dissertation, Harvard University, United States -Massachusetts. Retrieved August 17, 2004, from ProQuest Digital Dissertations database. (Publication No. AAT 9968319).

No Child Left Behind Act of 2001, Pub. L. No. 107-110, 115 Stat. 1425 (2002).

Nolen, J.L. (2003). Multiple intelligences in the classroom. Education, 124(1), 115119.

Shearer, C.B. (2004a). Multiple intelligences after 20 years. Teachers College Record, 106(1), 2-16. 
Shearer, C.B. (2004b). Using a multiple intelligences assessment to promote teacher development and student achievement. Teachers College Record, 106(1), 147162.

Silver, H.F., Strong, R.W., \& Perini, M.J. (2000). So each may learn. Integrating learning styles and multiple intelligences. Alexandria, VA: Association for Supervision and Curriculum Development.

Slavin, R.E. (1987). Ability grouping and student achievement in elementary schools: A best-evidence synthesis. Review of Educational Research, 57, 347-350.

Slavin, R.E. (1990). Ability grouping and student achievement in secondary schools: A best-evidence synthesis. Review of Educational Research, 60(3), 471-499.

Slavin, R.E. (1986). Best-evidence synthesis: An alternative to meta-analytic and traditional reviews. Educational Researcher, 15(9), 5-11.

Slavin, R.E. (1995). Best evidence synthesis: An intelligent alternative to metaanalysis. Journal of Clinical Epidemiology, 48(1), 9-18.

Slavin, R.E. (2004). Education research can and must address "what works" questions. Educational Researcher, 33(1), 27-28.

Slavin, R.E. (1984). Meta-analysis in education. How has it been used? Educational Researcher, 13(8), 6-15, 24-27.

Slavin, R.E., \& Cheung, A. (2003). Effective programs for English language learners: A best-evidence synthesis. Baltimore: Johns Hopkins University, Center for Research on the Education of Students Placed at Risk. 
Snyder, R.F. (2000). The relationship between learning style/multiple intelligences and academic achievement of high school students. High School Journal, 83(2), 1120.

Sohn, S.C. (2003). A method for introducing Gardner's theory of multiple intelligences to middle school students. Ph.D. dissertation, Boston College, United States -Massachusetts. Retrieved August 17, 2004, from ProQuest Digital Dissertations database. (Publication No. AAT 3103223).

VanGilder, J.S.C. (1995). A study of multiple intelligence as implemented by a Missouri school. Ed.D. dissertation, University of Arkansas, United States -Arkansas. Retrieved August 17, 2004, from ProQuest Digital Dissertations database. (Publication No. AAT 9608005).

Walker, K.L. (2001). The utilization of multiple intelligences to differentiate instruction in a middle school setting. Ed.D. dissertation, Bowling Green State University, United States -- Ohio. Retrieved August 17, 2004, from ProQuest Digital Dissertations database. (Publication No. AAT 3038427). 


\section{VITA \\ Ethan E. Hodge}

\section{EDUCATION}

\section{EXPERIENCE}

August 2002 to present

Spring Quarter 2002
(10 weeks)

\section{Regent University}

Virginia Beach, VA

Doctor of Education (Ed.D.) - matriculated into program Summer 2005, anticipated completion of program - 2008-2009. Doctoral core classes with Educational Psychology cognate, emphasis in Human Learning and Development.

\section{Cedarville University}

Cedarville, $\mathrm{OH}$

Master of Education (M.Ed.) - August 2005, GPA 4.0.

Teacher leadership core with concentration in Curriculum, Instruction, and Personnel Development. Applied research thesis entitled, "A Best-Evidence Synthesis of the Relationship of Multiple Intelligence Instructional Approaches and Student Achievement Indicators In Secondary School Classrooms.” Additional graduate coursework completed at Wright State University and University of Dayton.

\section{Cedarville University}

\section{Cedarville, $\mathbf{O H}$}

Bachelor of Arts (B.A.) with Honors - June 2002

Majors in History/Political Science (GPA 3.61) and Integrated Social Studies Education (GPA 3.85).

Undergraduate Activities and Honors - Edmund Burke Award for Distinction in Social Science and History (2002); Who's Who Among Students in American Universities and Colleges (2002); Student Representative - Educational Policies Advisory Committee to Academic Vice President (2001-2002); Pi Sig ma Alpha - secretary-treasurer (2001-2002); Resident Assistant (2000-2002); High School Tutoring Ministry (2001-2002); Student Government Association Interclass Council (1998-2000); Class of 2002 Treasurer (1998-2000); Dean's Honor List; National Deans' List.

Springboro Community City Schools Springboro Junior High School

Springboro, $\mathbf{O H}$ Classroom Teacher $-7^{\text {th }}$ Grade Social Studies (General and Enriched Classes)

- Daily responsibility for the instruction of approximately 150 students; consistent use of multiple learning modalities and effective classroom management techniques; successful daily interaction with administrators, colleagues, and parents; and implementation of intervention strategies for students with varied exceptionalities. Other responsibilities include organizing content knowledge for student learning, creating a classroom environment conducive to student learning, providing instruction that develops higherlevel thinking skills, and an ongoing commitment to personal and professional development.

Fairborn City Schools

Fairborn, $\mathbf{O H}$

Fairborn High School

Student Teaching-11 ${ }^{\text {th }}$ and $12^{\text {th }}$ Grade Civics and $9^{\text {th }}$ Grade United States History

- Assumed all classroom and extracurricular duties of the regular classroom teacher. Created individualized instructional materials and daily lesson plans; consistently demonstrated effective classroom management techniques; engaged in effective daily interaction with administrators, faculty colleagues, and parents. 


\section{VITA \\ Ethan E. Hodge}

PROFESSIONAL and COMMUNITY INVOLVEMENT
- Participation on various faculty committees including:

District Local Professional Development Committee;

District Social Studies Curriculum Alignment and Mapping Committee;

National Junior Honor Society Faculty Council;

Building Dress Code Revision Committee;

Building Discipline Committee;

District Educational Technologist Search and Interview Committee;

Making Middle Grades Work committees; and various other committee work.

- Extensive knowledge of and involvement with classroom and curricular implementation the Ohio Academic Content Standards for social studies.

- Participant in district mentoring (OhioFIRST) entry-year program in preparation for successful completion of Praxis III assessment in 2003.

- Certified as a Pathwise Mentor Teacher through University of Dayton.

- Awarded 2002-2003 Springboro Co mmunity Schools Educational Services Mini-Grant for purchase of notebook computer to increase and enhance use of technology in the classroom.

- Participant in Lectora Publisher software pilot study in conjunction with district Educational Technologist.

- Participant in SOITA/GMVETC Educational Technology Conference in Dayton,

- Participant in OAGC Teacher Academy in Columbus,

- Participant in Ohio SchoolNet Technology Conference in Columbus.

- Participant in district training and implementation of Progress Book - fully featured Internet-based grade book package including lesson planning, alignment with state indicators, and web access to student and class information by parents and students.

- Faculty sponsor of student-led L.I.F.T. (Living in Faith Together) after-school Bible study and community service group.

- Association for Supervision and Curriculum Development comprehensive member.

- Active member of Hillcrest Baptist Church in Carlis le, OH; actively involved with College and Career Ministries. 
